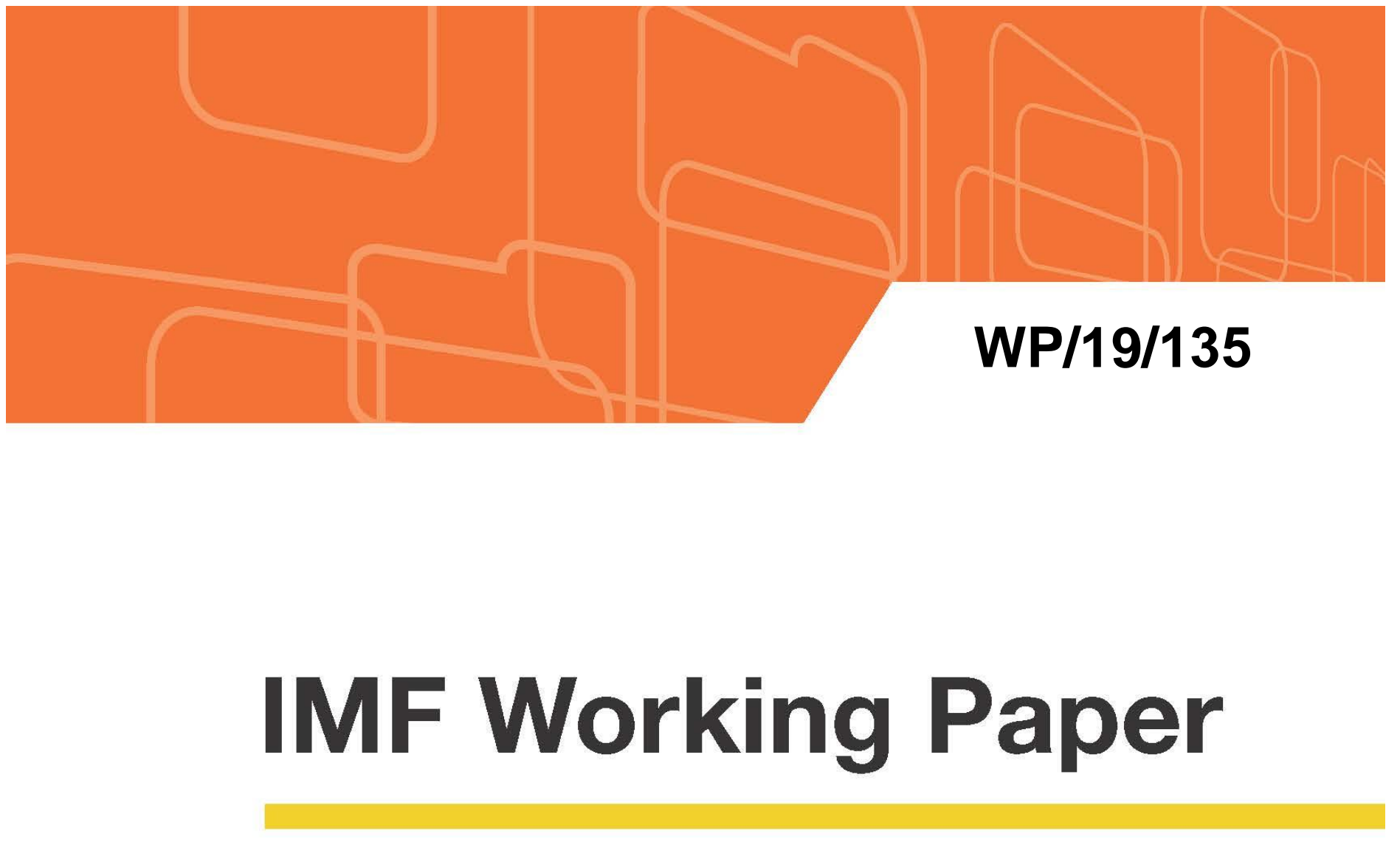

\title{
E-commerce as a Potential New Engine for Growth in Asia
}

by Tidiane Kinda

IMF Working Papers describe research in progress by the author(s) and are published to elicit comments and to encourage debate. The views expressed in IMF Working Papers are those of the author(s) and do not necessarily represent the views of the IMF, its Executive Board, or IMF management. 


\title{
IMF Working Paper
}

Asia and Pacific Department

\section{E-commerce as a Potential New Engine for Growth in Asia \\ Prepared by Tidiane Kinda ${ }^{1}$}

Authorized for distribution by Luis E. Breuer

July 2019

\section{IMF Working Papers describe research in progress by the author(s) and are published to elicit comments and to encourage debate. The views expressed in IMF Working Papers are those of the author(s) and do not necessarily represent the views of the IMF, its Executive Board, or IMF management.}

\begin{abstract}
The use of e-commerce around the world has accelerated in recent years, with Asia, led by China, spearheading the rise. Using cross-country enterprise survey data, this paper shows that firms engaged in e-commerce have higher productivity and generate a larger share of their revenues from exports than other firms. This is particularly true in Asia, where firms have 30 percent higher productivity and generate about 50 percent more of their revenues from exports. The results presented in this paper are robust to the use of instrumental variables, which highlight possible larger effects of e-commerce on Asian productivity and exports when essential elements are in place for its effective use, such as reliable electricity, telecommunication, and transport infrastructure. Despite the rapid growth of e-commerce in recent years, gaps persist in digital infrastructure and legislation, preventing many Asian countries from fully reaping the potential benefits of e-commerce.

JEL Classification Numbers: C21, L25, O14

Keywords: e-commerce, productivity, exports

Author's E-Mail Address: tkinda@imf.org

\footnotetext{
${ }^{1}$ The author would like to thank John Bluedorn, Francesco Grigoli, Kenneth Kang, Koshy Mathai, Gian M. Milesi-Ferretti, Joannes Mongardini, Jonathan Ostry, Changyong Rhee, Tahsin S. Sedik, and participants in the IMF interdepartmental surveillance meeting for helpful comments, as well as Nong Jotikasthira and Simon Paroutzoglou for production and research assistance. The initial results of this paper were published in the October 2018 Regional Economic Outlook: Asia and Pacific.
} 
I. Introduction 3

II. E-commerce in Asia: A Fast-Growing Sector ........................................................4

III. E-commerce as a Potential New Engine for Growth ..........................................

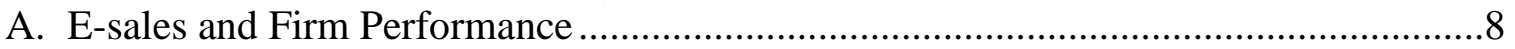

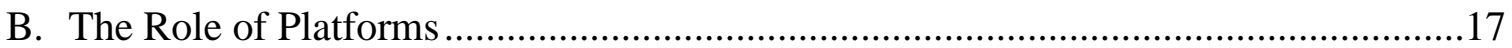

C. Enabling Factors: Significant Growth Potential for E-commerce in Asia..................19

IV. Conclusion

Box

1. E-commerce in Indonesia .................................................................................22

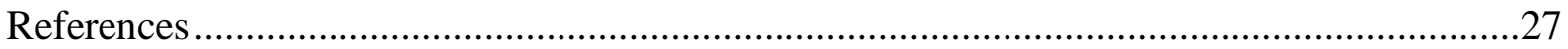

Figures

1. Global B2B and B2C E-commerce, 2013-17 ...........................................................

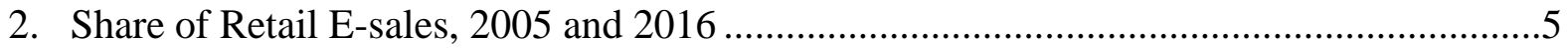

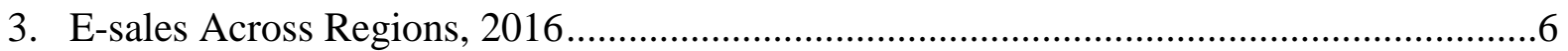

4. E-sales Across Selected Countries, 2016 ..................................................................6

5. Digital Payment Across Regions, 2017 ...................................................................6

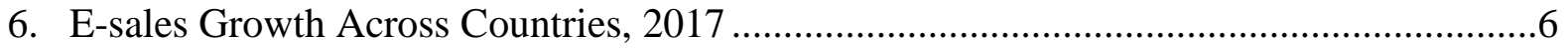

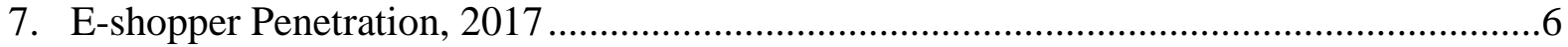

8. Share of Internet Users, 2017 ............................................................................6

9. E-sales and Selected Macroeconomic Outcomes, 2012-17 ..........................................8

10. Labor Productivity Differences Between Online and Other Firms ................................11

11. Distribution of Total Factor Productivity ................................................................ 12

12. Estimated Impact of E-commerce Participation on Productivity and Export...................14

13. Platform and Multiple Network Effects.................................................................... 18

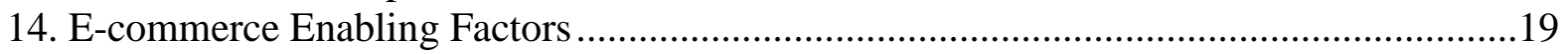

15. Share of Asian Countries with E-commerce Legislation..............................................20

Tables

1. Selected Characteristics of E-commerce Firms ..........................................................10

2. E-commerce, Total Factor Productivity, and Export: Ordinary Least Squares .................15

3. E-commerce, Total Factor Productivity, and Export: Instrumental Variable Approach ...17

Appendix Tables

1. Country List.

2. Estimation of Total Factor Productivity ...............................................................23

3. E-commerce, Total Factor Productivity, and Exports: Instrumental Variable Approach with the Limited Information Maximum Likelihood (LIML) Estimator.....................24

4. E-commerce, Total Factor Productivity, and Exports: Alternative Instruments and Sub-sample of Middle-Income Countries .............................................................25

5. Status of E-commerce Legislation in Asia and the Pacific ...........................................26 


\section{INTRODUCTION}

Electronic commerce or e-commerce can be defined as the use of the Internet to conduct business transactions nationally or internationally. It mainly involves buying and selling products or services through online transactions, coupled with transport logistics for pickup and delivery. E-commerce can take place between businesses, such as a manufacturer and a wholesaler (business to business - B2B), or between a business and a consumer (business to consumer - B2C). Although B2C e-commerce tends to receive significant attention, B2B transactions actually exceed $\mathrm{B} 2 \mathrm{C}$ transactions. ${ }^{2}$

Suppported by the global digital revolution (IMF 2018), the use of e-commerce has accelerated in recent years. ${ }^{3}$ Asia, led by China, is playing a leading role in nearly every aspect of digitalization, including e-commerce. From less than 1 percent about a decade ago, China's share in global e-commerce retail transaction value has grown to more than 40 percent (Woetzel and others 2017). Beyond China, a diverse set of Asian economies, including Japan, India, Indonesia, South Korea, and Vietnam, also have a robust and dynamic e-commerce sector.

E-commerce offers unprecedented opportunities to businesses and consumers. It expands the marketplace by giving consumers the ability to purchase a wider range of products and services from both local and foreign businesses. E-commerce is also transforming the way firms operate. For instance, by redefining inventory management, distribution, and customer services, e-commerce is fostering new supply networks, services, and business models. These have often been associated with efficiency improvements, better asset utilization, faster delivery to market and consumers, and improved customer services.

Despite the rapid rise of e-commerce in recent years and its potential economic impact, there has been limited empirical evidence quantifying how much e-commerce can boost economic outcomes. The few existing studies suggest an overall positive effect of e-commerce on firm performance. Using firm-level data for 14 European economies covering 2002-10, Falk and Hagsten (2015) show that an increase in e-sales by 1 percentage point raises labor productivity growth by 0.3 percentage points, with a larger effect for small firms and firms in the services sector. Yang, Shi, and Yan (2017) show that e-commerce participation has the potential to positively impact firm productivity in China. World Bank (2016) shows that

\footnotetext{
${ }^{2}$ Statista estimated the gross merchandise volume of global B2B e-commerce transactions at US $\$ 7.7$ trillion in 2017. During the same year, global retail B2C e-commerce sales amounted to an estimated US $\$ 2.3$ trillion.

${ }^{3}$ IMF (2018) analyzes various aspects of the digital revolution, including automation, Fintech, and e-commerce, which have accelerated recently as a result of rapid advances in artificial intelligence, robotics, computing power, cryptography, and big data.
} 
firms using e-commerce in Vietnam had on average 3.6 percentage points higher total factor productivity (TFP) growth than firms not using e-commerce.

The topic of this study is a rapidly evolving area where any empirical exercise, particularly cross-country exercises and those involving Asian countries, is severly contrained by limited data. In this context, this paper attemps to contribute to the empirical literature on e-commerce through four main points. First, it briefly analyzes the e-commerce landscape and highlights that Asia, and in particular China, is at the forefront of global e-sales dynamism. Second, it shows that firms engaged in online activities have higher productivity and larger exports, even more so in Asia. Third, it stresses that by enhancing network effects, platforms have the potential to magnify the benefits of e-commerce, although they may also raise competition issues. Fourth, it discusses various dimensions of infrastructure and delivery services that many countries in Asia could improve in order to better reap the benefits of e-commerce.

The rest of the paper is organized as follows. Section 2 describes the landscape of e-commerce, with a special focus on Asia. Section 3 assesses the potential role of e-commerce as a new engine for growth in Asia, focusing on its potential impact on firm productivity and exports, while highlighting existing gaps that need to be addressed in order to fully reap the benefits of e-sales. Section 4 offers concluding remarks.

\section{E-COMMERCE In ASIA: A FAST-Growing SECTOR}

The world has seen unprecedented growth in e-commerce in recent years. From US $\$ 1.3$ trillion in 2014, global retail e-commerce sales almost doubled during the following three years to reach an estimated US\$2.3 trillion in 2017 (Figure 1). During the same period, global B2B e-commerce gross merchandise volume also increased by 20 percent, although from a higher base - from US\$6.4 trillion in 2014 to US\$7.7 trillion in 2017. This rapid growth was spearheaded by strong dynamism in Asia, particularly China. China's share in global e-commerce retail transaction value has exploded to more than 40 percent today from less than 1 percent about 10 years ago (Figure 2). In comparison, the U.S. share of the market is currently 24 percent, down from 35 percent in 2005. China's dominance in e-commerce is unparalleled. The value of China's e-commerce transactions is estimated to be larger than in France, Germany, Japan, the United Kingdom, and the United States combined (Woetzal and others 2017).

Asia's 12 percent share of retail sales that occurs via e-commerce surpasses the respective shares of 8 percent for Western Europe and North America, with China again in the lead (Figures 3 and 4). Internet connectivity and mass adoption of mobile technologies and digital payments have made it easier for e-commerce companies to target and reach consumers in the region. For instance, the rapid growth of e-commerce in China has been powered by the world's largest Internet population and the surge in the use of mobile payments. China alone hosts more than 700 million Internet users, and online shoppers are increasingly buying via 
their mobile devices. Between 2013 and 2016, mobile payments soared from 25 to 68 percent of mobile Internet users. Consumption-related mobile payments in China totaled US $\$ 790$ billion in 2016 - 11 times that of the United States, which has 262 million mobile Internet users (Woetzel and others 2017).

Asia's stellar growth in e-commerce is not limited to China, as India, Japan, and South Korea are among the economies with the largest shares of e-commerce sales in retail sales worldwide (Figure 4). Other Asian countries, such as Indonesia and Vietnam, are also experiencing rapid growth in e-sales, supported by digital payments, which are more used in the region (Figure 5). For instance, the share of e-sales in total retail sales increased fourfold between 2014 and 2017 in Indonesia, though it remains below 5 percent. As in China and India, revenues from e-sales in Indonesia increased by more 20 percent in 2017, buoyed by a young and digitally savvy population (Figure 6; see also Box 1 for a description of the fastrising e-commerce sector in Indonesia).

Despite the rapid growth of e-commerce in Asia in recent years, the share of the online population that bought a product online (known as e-shopper penetration) remains below 50 percent and is among the lowest globally (Figure 7). Combined with the large population and the already great number of Internet users, this highlights that there is a large and stilluntapped market in Asia, and as such considerable potential to grow e-commerce there. Looking forward, the potential for e-commerce growth in Asia is even larger, considering that a large part of the population remains offline in many countries, particularly in rural areas (Figure 8).
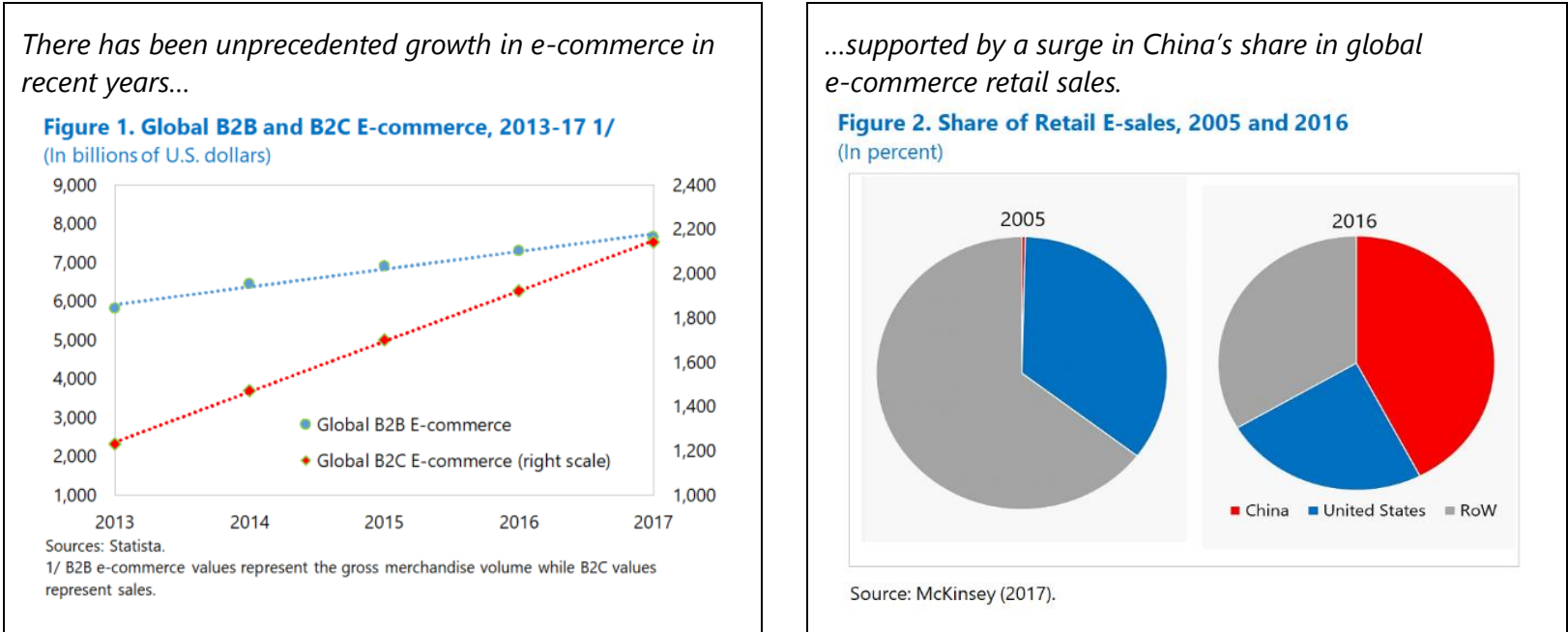


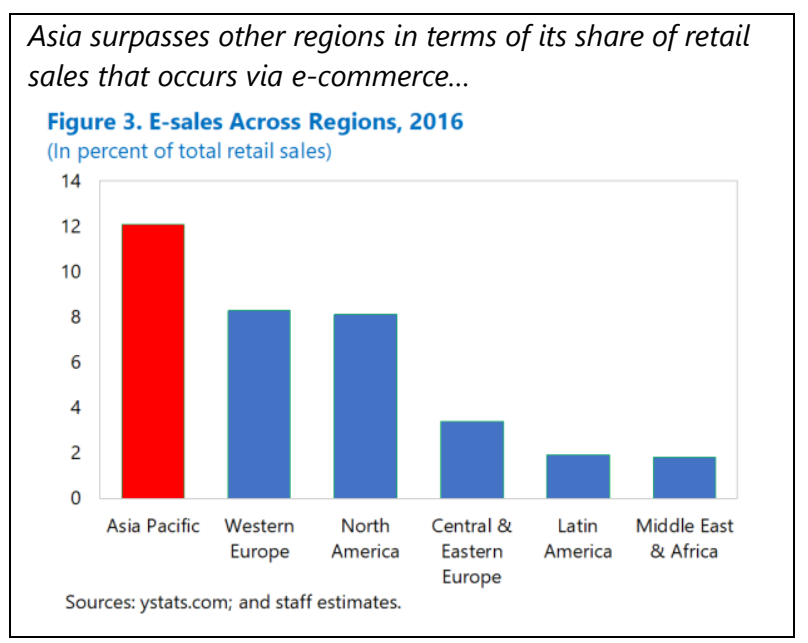

\section{Asia's rapid growth in e-sales has been supported by} strong use of digital payments.

Figure 5. Digital Payment Across Regions, 2017 (In percent of population aged 15+)

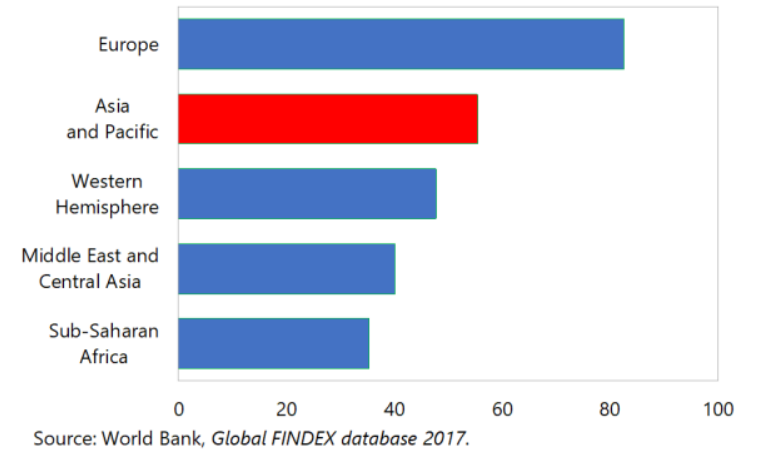

Yet, e-penetration in Asia remains low, as less than half of the region's online population has made a purchase online...

\section{$S$}

Figure 7. E-shopper Penetration, 2017

(In percent of total internet user)

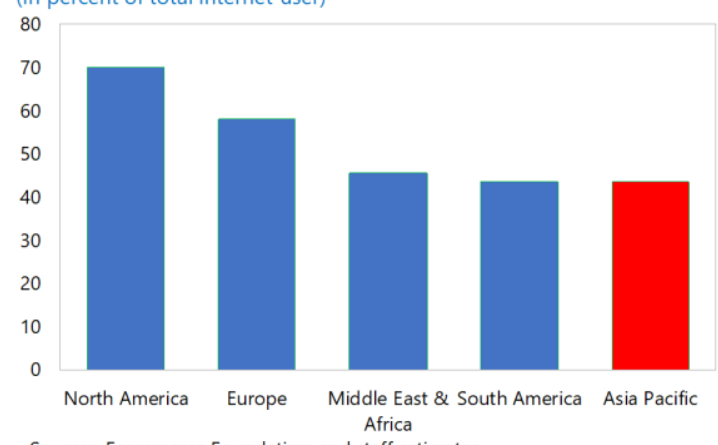

Sources: Ecommerce Foundation; and staff estimates. ...with China as well as other countries in the region such as South Korea and Japan in the lead.

Figure 4. E-sales Across Selected Countries, 2016

(In percent of total retail sale)

25

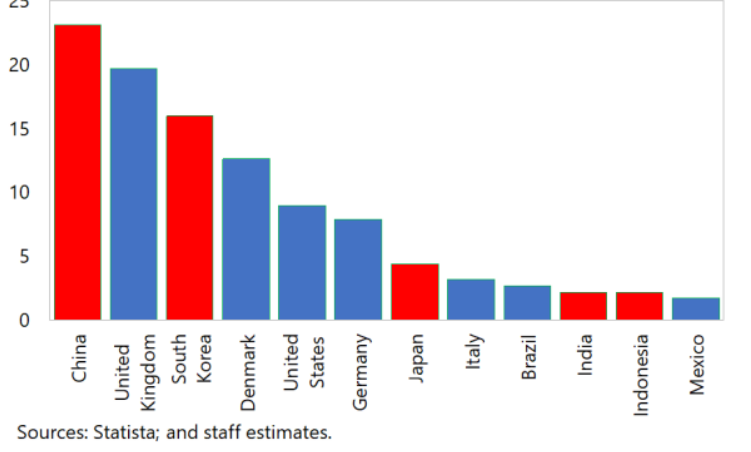

Sources: Statista; and staff estimates.

Other Asian countries, such as India and Indonesia, are also experiencing rapid growth in e-sales.

Figure 6. E-sales Growth Across Countries, 2017 (Percentage change)

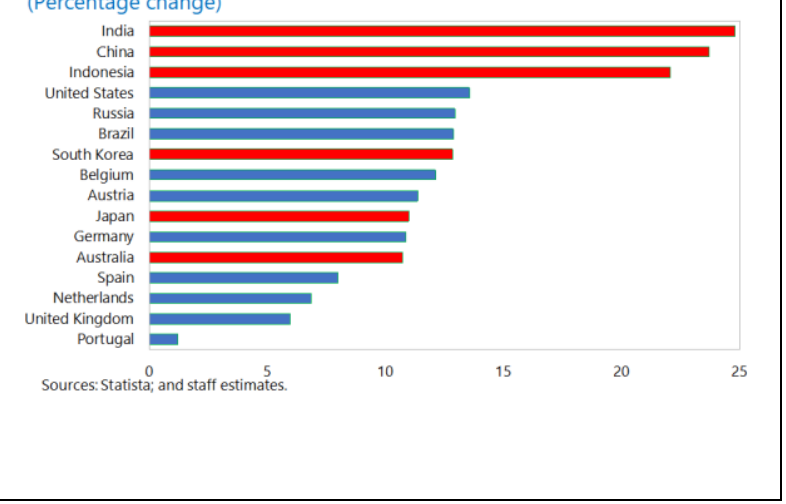

...and a large part of Asian population remains offline in many countries.

Figure 8. Share of Internet Users, 2017

(In percent of population)

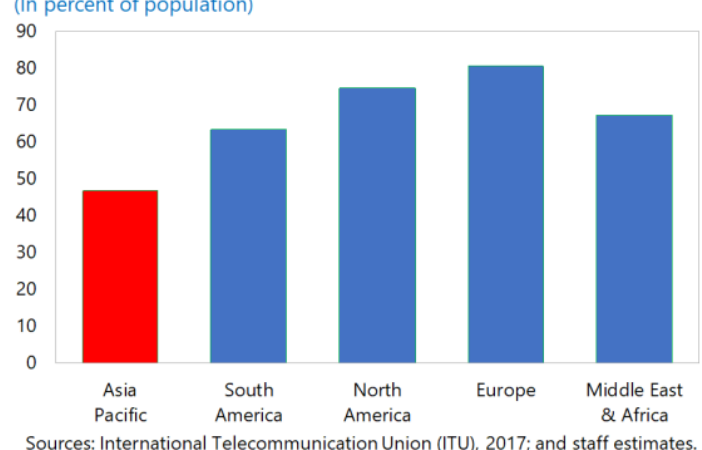




\section{E-Commerce as a Potential New Engine for Growth}

E-commerce has the potential to boost private consumption and investment at the aggregate level. For consumers, e-commerce may translate into better access to a wide range of products and services at potentially lower prices, ultimately boosting consumption. Two studies by McKinsey in China and Indonesia highlight that e-commerce generates new consumption. In China, a study shows that for every US\$100 in Internet spending, close to 40 percent represents incremental (new) consumption, while the remaining 60 percent is diverted from traditional offline retail channels (Dobbs and others 2013). In Indonesia, about 30 percent of online commerce spending is new consumption, capturing previously untapped needs (Das and others 2018). A recent study on the United States (Dolfen and others 2019) estimate that e-commerce spending reached 8 percent of consumption by 2017, yielding consumers the equivalent of a 1 percent permanent boost to their consumption, or over US $\$ 1,000$ per household. While some of the gains arose from saving travel costs of buying from local merchants, most of the gains stemmed from substituting to online merchants. Higher income consumers gained more, as did consumers in more densely populated counties. For firms, e-commerce could also provide new business opportunities and access to larger markets, supporting investment.

While data limitation is a major constraint to any substantive cross-country analysis, particularly at the macro level, tentative correlations seem to suggest that private consumption and private investment growth could potentially be positively correlated with e-sales (Figure 9). ${ }^{4}$

\footnotetext{
${ }^{4}$ While e-sales seem to be associated with higher consumption growth, the analysis does not find evidence that economies with higher e-sales have a higher share of private consumption to GDP.
} 
Figure 9. E-sales and Selected Macroeconomic Outcomes, 2012-17

1. GDP Growth

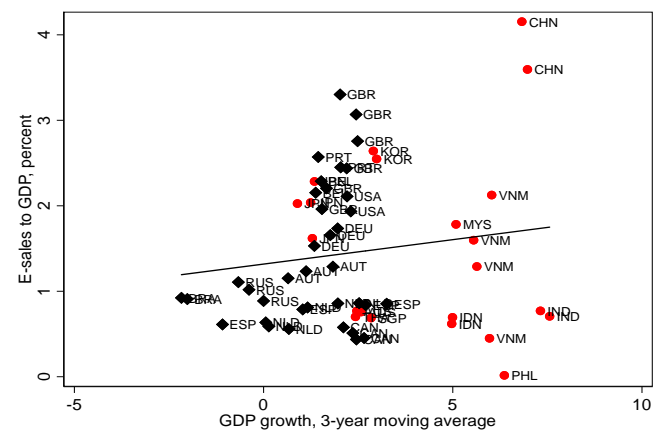

3. Private Investment Growth

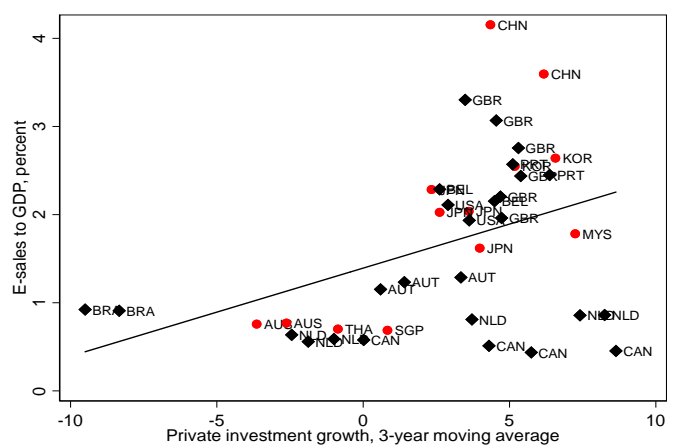

2. Private Consumption Growth

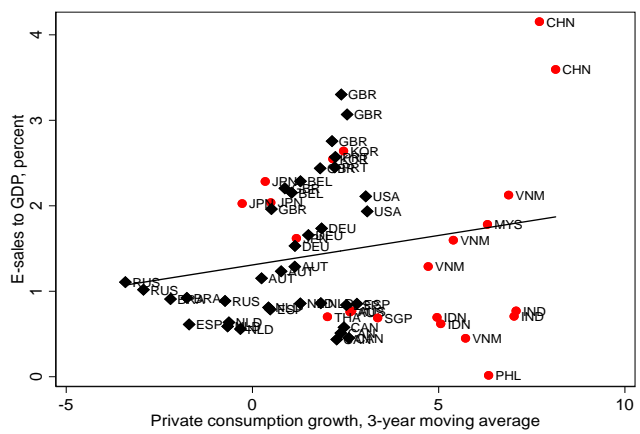

4. Private Consumption

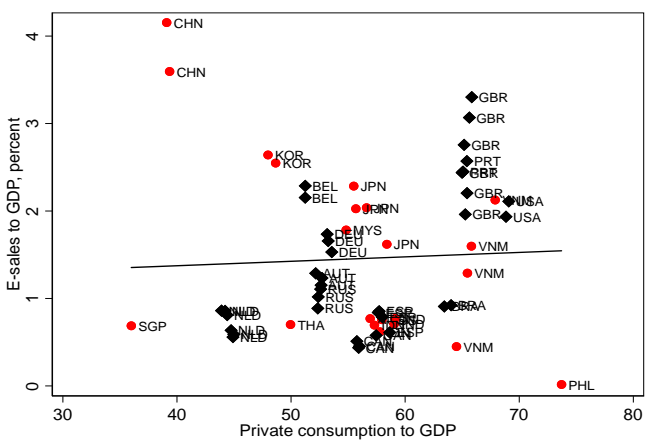

Source: Statista; IMF, World Economic Outlook; and IMF staff estimates.

\section{A. E-sales and Firm Performance}

In the context of scarce data, particularly at the macro level, this paper relies on crosscountry, firm-level data to empirically assess the potential economic benefits of e-commerce, with a particular focus on Asia. It provides a novel analysis that investigates performance differences between firms engaged in e-commerce and other firms.

\section{World Bank Enterprise Survey Data}

This paper relies on data from the World Bank Enterprise Surveys (WBES), which are standardized and conducted across large and representative samples of firms. This allows for national and international comparisons of productive performance across activities in the manufacturing and services sectors. The WBES data include information on firms' inputs (stock of capital, number of employees, compensation of workers) and outputs (sales, exports), as well as various characteristics such as age, size, and foreign ownership. Various aspects of the investment climate, including access to infrastructure, finance, and human capital, as well as the capacity of firms to innovate, are also covered in the dataset. The variable of interest, e-commerce, is a dummy taking one if a firm uses an Internet connection to order purchases from other establishments or to deliver products and services to clients. 
The analysis in this paper uses a comprehensive sample of developing economies across all regions, including six Asian economies (China, Indonesia, Mongolia, Nepal, the Philippines, and Vietnam) during the period 2006-12. ${ }^{5}$

\section{Some Stylized Facts}

Firms with online activities stand out on many fronts. These firms tend to be more present in several activities. In the manufacturing sector, firms engaged in more sophisticated production such as chemicals and machinery have a greater online presence than firms engaged in more traditional manufacturing such as textile or mineral production. Some heterogeneity also exists in the service sector. Firms in retail or wholesale, and especially in information technology (IT) services, have a much greater online presence than firms in transport, storage, or food businesses. Evidence from the WBES also suggests that firms engaged in e-commerce tend to be more innovative, have a more educated labor force, and have better access to finance than other firms, including in Asia (Table 1).

Relative to other firms, a larger share of firms involved in e-commerce introduced new products or processes, used technology licensed from a foreign company, spent on research and development (R\&D), or acquired internationally recognized quality certifications. For instance, compared to 42 percent for other firms, 63 percent of e-commerce firms in Asia have internationally recognized quality certifications. While more than half of Asian e-commerce firms introduced new products or services in recent years, only about a third of Asian firms not involved in e-commerce were that innovative. A larger share of e-commerce firms, particularly in Asia, provides formal training to their employees, supporting their capacity to innovate and maintain high quality standards. Possibly reflecting the above factors, e-commerce firms tend to enjoy higher sales, value added, stock of capital, and exports than non-e-commerce firms. In Asia, e-commerce firms' median sales are about 73 percent larger and their exports almost twice larger than other firms.

\footnotetext{
5 The sample for the analysis is comprised of 77 developing economies covering all regions that are pulled together to construct a cross-country firm-level dataset. Each survey was carried out between 2006 and 2012. Appendix Table 1 provides the list of countries.
} 
Table 1. Selected Characteristics of E-commerce Firms

(In percent, unless otherwise indicated)

\begin{tabular}{|c|c|c|c|c|}
\hline & \multicolumn{2}{|c|}{ All Countries } & \multicolumn{2}{|c|}{ Asia } \\
\hline & E-commerce & Other firms & E-commerce & Other firms \\
\hline \multicolumn{5}{|l|}{ Innovation } \\
\hline Firms owning a website & 70.9 & 53.6 & 76.0 & 57.4 \\
\hline Communicate by e-mail with clients and suppliers & 97.5 & 82.9 & 94.0 & 72.3 \\
\hline Use of technology licensed from a foreign company & 21.2 & 13.4 & 28.9 & 10.4 \\
\hline Internationally-recognized quality certification & 32.1 & 24.0 & 62.9 & 42.3 \\
\hline New products/services introduced during last 3 years & 59.1 & 45.0 & 51.2 & 36.5 \\
\hline Improved process introducted during last 3 years & 57.8 & 46.5 & 71.1 & 51.1 \\
\hline Did the firm spend on R\&D during last fiscal year & 50.4 & 36.6 & 46.7 & 33.0 \\
\hline \multicolumn{5}{|l|}{ Human capital } \\
\hline Workers with completed high school education & 73.0 & 63.7 & 61.8 & 56.1 \\
\hline Workers with high university degree & 10.4 & 9.8 & 10.3 & 9.8 \\
\hline Firms with formal training to employee last fiscal year & 65.8 & 59.9 & 88.1 & 77.6 \\
\hline \multicolumn{5}{|l|}{ Finance } \\
\hline Firms with line of credit or loan & 53.9 & 42.8 & 36.8 & 23.9 \\
\hline Firms with overdraft facility & 59.4 & 47.6 & 33.9 & 27.2 \\
\hline \multicolumn{5}{|l|}{ Performance } \\
\hline Annual sales (US\$ thousands, median) & $1,743.0$ & $1,157.1$ & $2,693.1$ & $1,552.5$ \\
\hline Value added (US\$ thousands, median) & 562.6 & 418.3 & $1,095.5$ & 619.4 \\
\hline Export in total sales & 6.7 & 4.2 & 7.4 & 3.8 \\
\hline Stock of capital (US\$ thousands, median) & 536.7 & 347.6 & $1,108.9$ & 712.9 \\
\hline
\end{tabular}

Sources: Enterprise Survey, World Bank; and IMF staff estimates.

However, while e-commerce firms have better access to human capital and finance, these firms seem to suffer more from other constraints of the investment climate. A higher share of e-commerce firms reports telecommunication and transport issues as well as customs and trade regulations as obstacles to conducting their activities. For example, compared to 8 percent for other firms, 14 percent of e-commerce firms in Asia perceive difficulties in transport as an obstacle for their operations. This is consistent with the critical role of logistics and trade regulations in e-commerce, especially cross-border e-commerce.

\section{Assessing the Performance of E-commerce Firms: A First Glance}

Various indicators can be used to assess firm performance, with each of them having its intrinsic strengths but also weaknesses. A common indicator, defined as the ratio of value added to the number of employees, captures labor productivity. While this indicator is immune from the usual measurement errors in the stock of capital, omitting capital from a performance indicator can be misleading, particularly for e-commerce firms, which tend to depend more on capital for their activities and as such invest more. 
A first look at labor productivity highlights that firms engaged in e-commerce activities have higher labor productivity (Figure 10). The difference in labor productivity seems higher in Asia, where e-commerce firms are on average 50 percent more productive than other firms. ${ }^{6}$

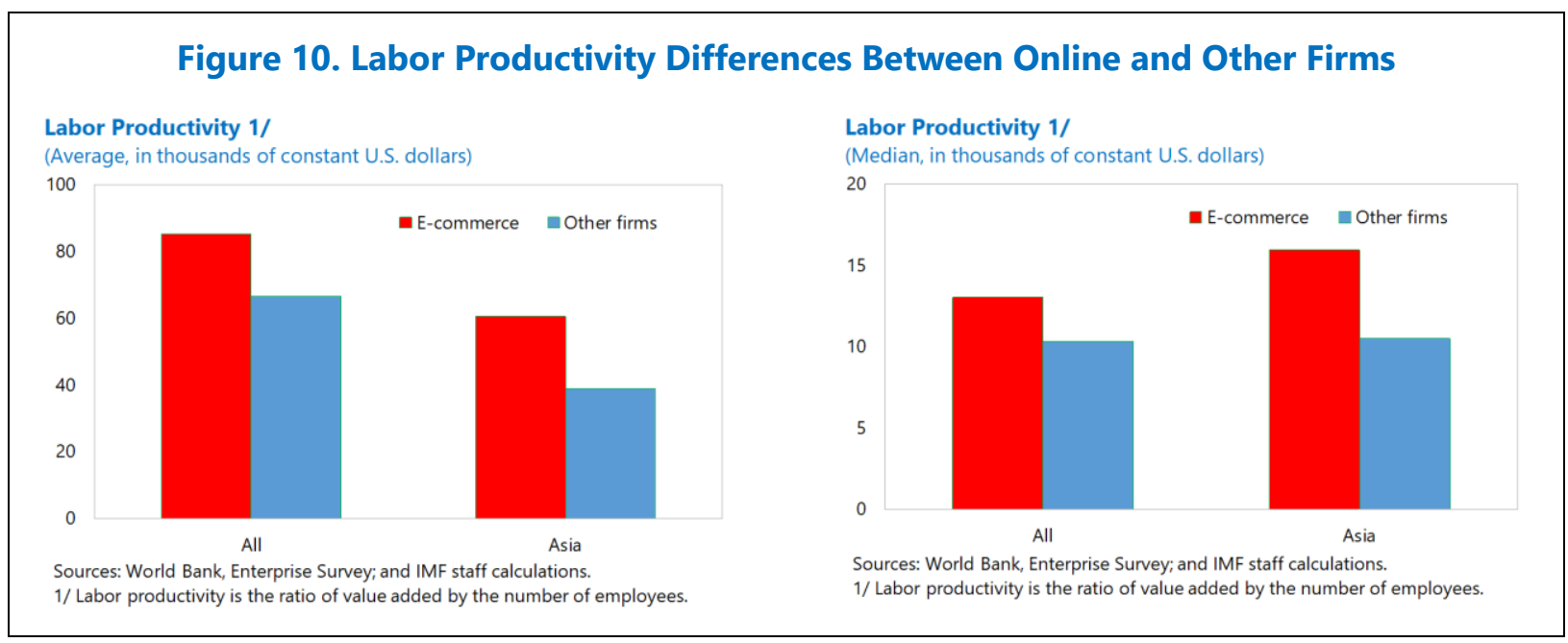

To capture a more complete picture of the performance differential between firms with online activities and other firms, this section analyzes differences in TFP. Estimating TFP allows for accounting for firms' stock of capital, which is an important element in the context of the present analysis. Each firm's TFP is estimated as a residual of the following equation explaining the value added of each firm by its number of employees and level of capital stock, assuming a basic Cobb-Douglas functional form:

$$
V A_{i j k}=\alpha L_{i j k}+\beta K_{i j k}+\gamma C_{i}+\delta S_{j}+\varepsilon_{i j k}
$$

where $V A_{i j k}$ captures the value added of each firm $i$, in country $j$, and sector $k ; L_{i j k}$ represents the number of employees, including temporary workers; and $K_{i j k}$ represents the level of capital stock. ${ }^{7}$ All variables are in logarithm terms. $C_{i}$ and $S_{j}$ are, respectively, country and sector fixed effects. The error term $\varepsilon_{i j k}$, which captures the residual of the value added not explained by labor and capital, is the measure of firm-level productivity. ${ }^{8}$

\footnotetext{
${ }^{6}$ Potential outliers (top 1 percent and bottom 1 percent of most/least productive firms) are excluded to avoid significant distortions of average figures.

${ }^{7}$ Sales, value added, and capital stock are converted into constant U.S. dollars.

${ }^{8}$ Appendix Table 1 provides the results of the estimations. The cross-sectional dimension of the data does not allow for more recent estimation techniques of TFP, such as those of Levinsohn and Petrin (2003) and Ackerberg, Caves, and Frazer (2015).
} 
Comparing the distribution of TFP between the two groups of firms confirms that firms with online activities have higher productivity, particularly in Asia. Interestingly, e-commerce seems to be especially beneficial for small firms in Asia (Figure 11).

Figure 11. Distribution of Total Factor Productivity

1. All Economies (All firms)

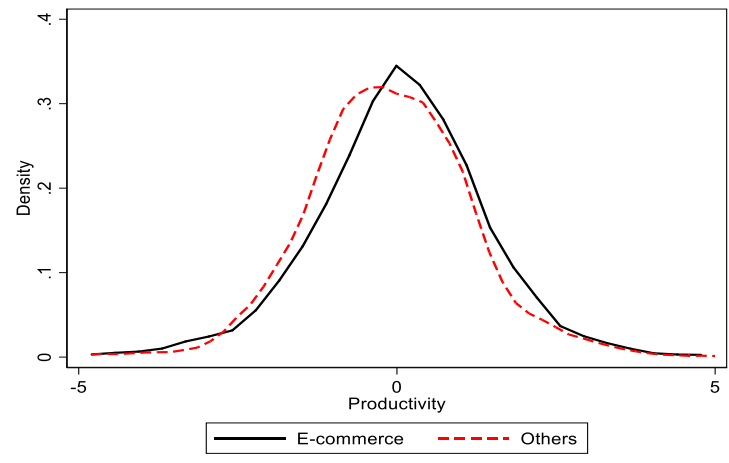

3. All Small Firms (Less than 20 employees)

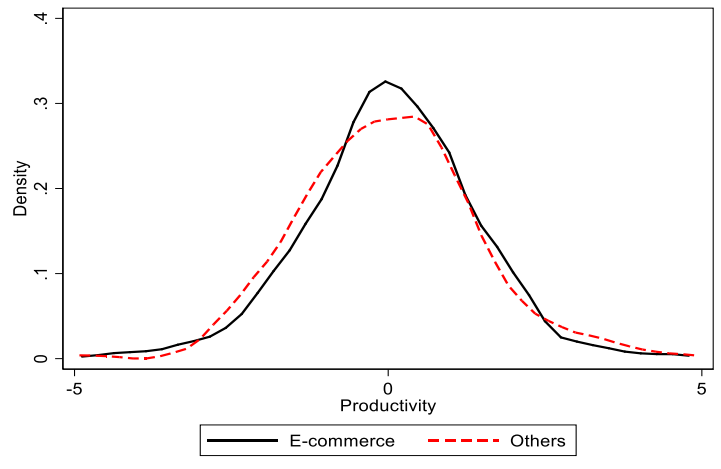

5. All Medium-Sized Firms (20-99 employees)

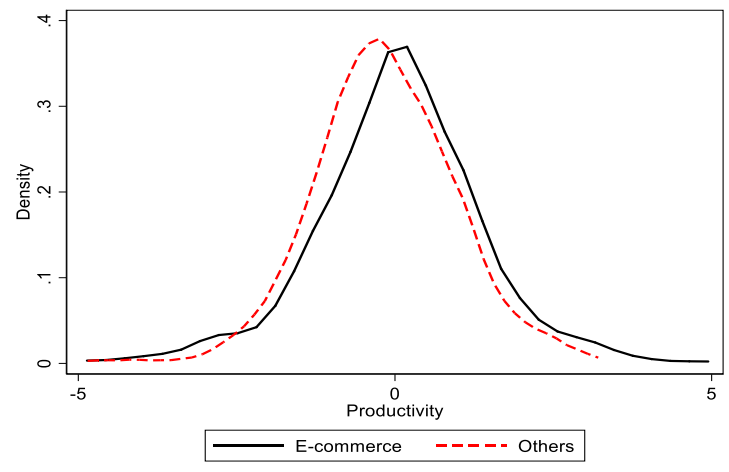

2. Asia (All firms)

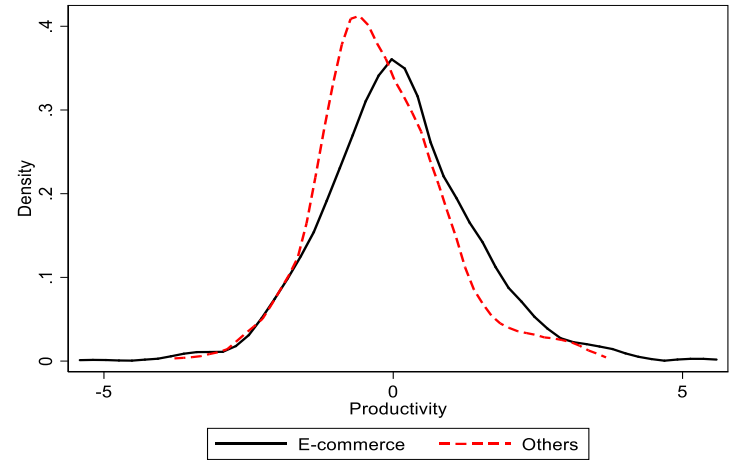

4. Asian Small Firms (Less than 20 employees)

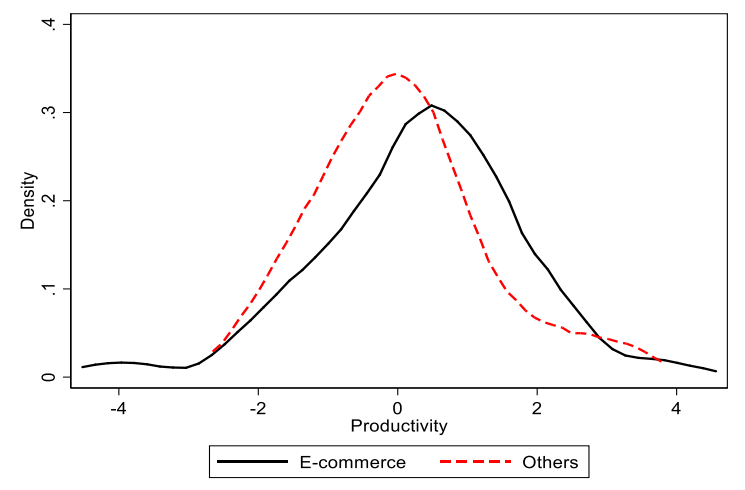

6. Asian Medium-Sized Firms (20-99 employees)

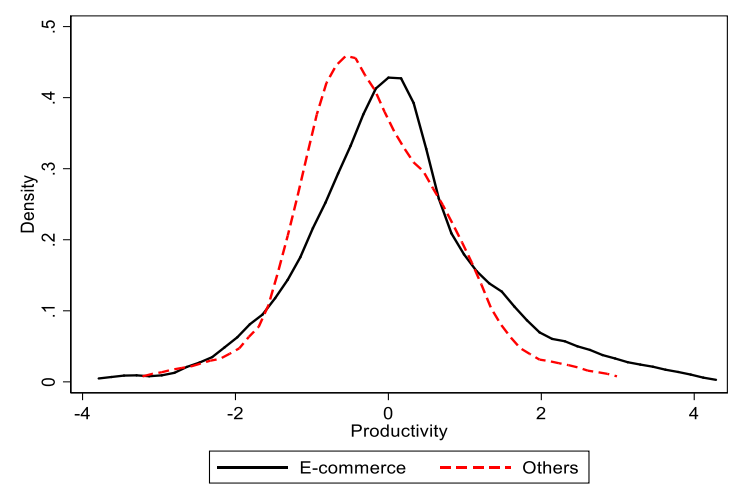


Figure 11. Distribution of Total Factor Productivity (Concluded)

7. All Large Firms (100 and more employees)

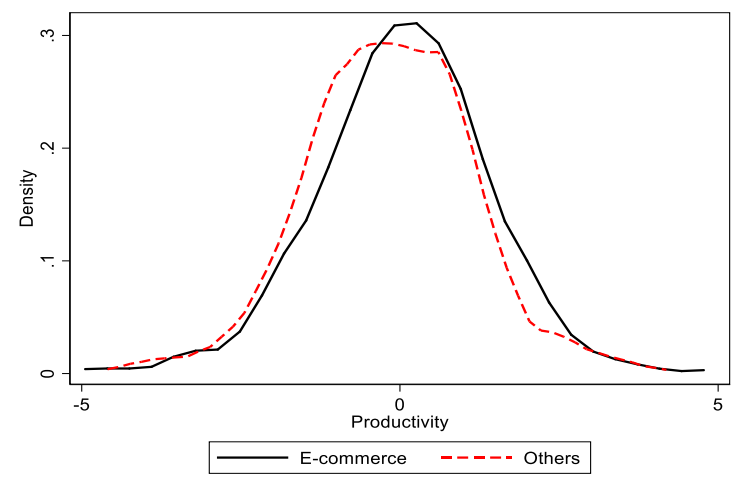

8. Asian Large Firms (100 and more employees)

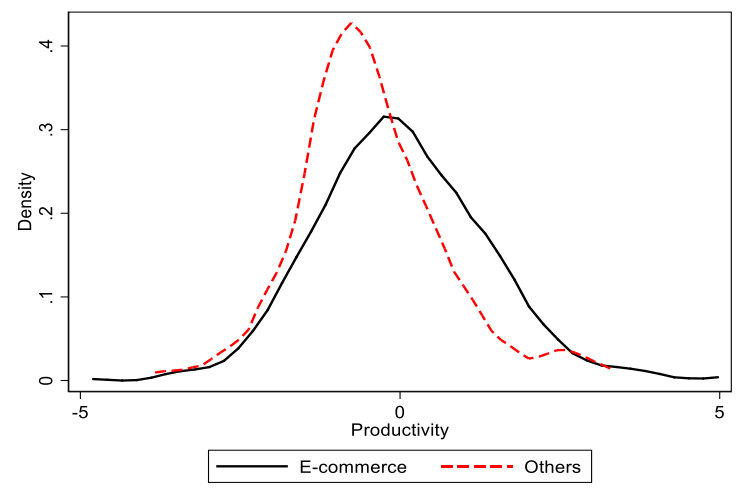

Source: Author's estimates using World Bank Enterprise Surveys.

\section{Assessing the Performance of E-commerce Firms: A Further Look}

The empirical literature identifies several firm characteristics and factors that tend to influence firm performance (Dollar, Hallward-Driemeier, and Mengistae 2005; Chaffai, Kinda, and Plane 2012; Kinda 2012). These include firm age, size, foreign ownership, export status, human capital, and access to finance. This section assesses the impact of e-commerce participation on firm-level TFP after accounting for these variables through the following equation:

$$
T F P_{i j k}=\alpha E c o m_{i j k}+\beta X_{i j k}+\gamma C_{i}+\delta S_{j}+\eta_{i j k}
$$

where $T F P_{i j k}$ captures firm-level TFP of firm $i$, in country $j$, and sector $k$, estimated from equation 1. Ecom $i j k$ is a dummy taking one if a firm uses an Internet connection to order purchases from other establishments or to deliver products and services to clients, and zero otherwise. $X_{i j k}$ is a matrix of common determinants of firm-level productivity identified in the literature, and it is comprised of firm size, age, share of foreign capital, share of exports, education of labor force, and access to finance. $C_{i}$ and $S_{j}$ are, respectively, country and sector fixed effects, and $\eta_{i j k}$ is the error term.

Controlling for firm characteristics confirms the main results. The suggestive evidence that firms (including small and medium-sized ones) involved in e-commerce are more productive holds after controlling for a number of firm characteristics (age, size, foreign ownership, export status, and education of labor force) that are also known to affect performance. The results show that participation in online commerce is associated with 14 percent higher TFP at the firm level (Figure 12, Panel 1; and Table 2). 
Figure 12. Estimated Impact of E-commerce Participation on Productivity and Export 1/

\section{a. Total Factor Productivity (Log)}

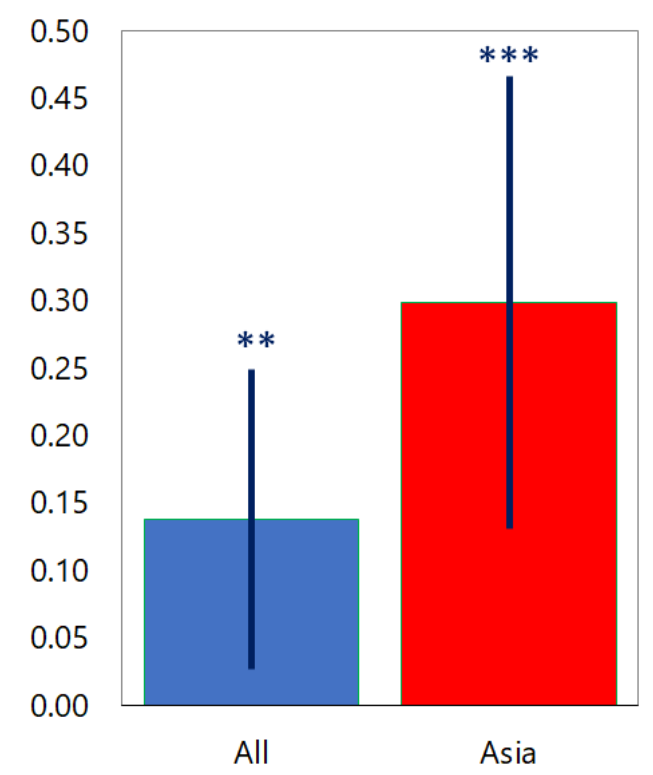

b. Share of Exports in Total Sales (In percent)

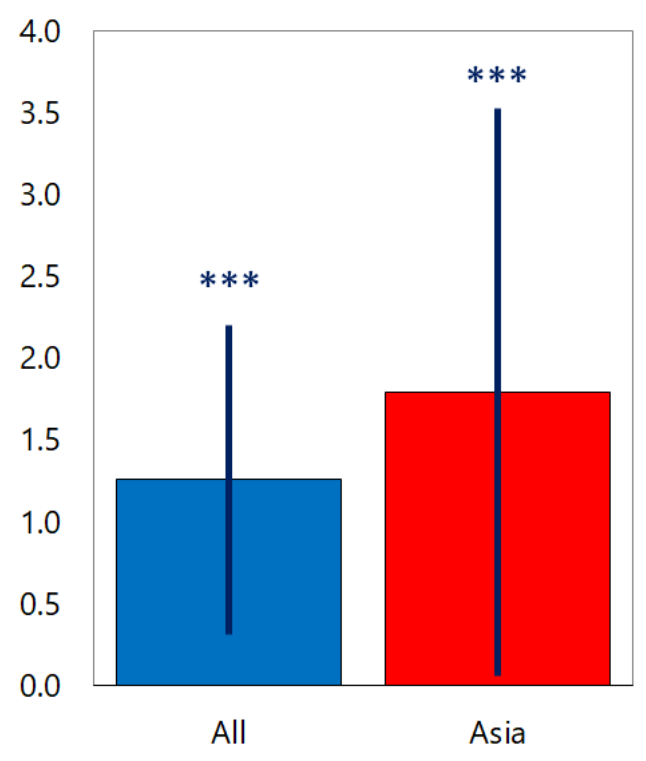

Source: World Bank Enterprises Surveys and IMF staff estimates.

1/ These figures illustrate coefficients and confidence intervals from two firm-level estimations: (a) the impact of e-commerce participation on total factor productivity controlling for firms' age, size, foreign ownership, export status, and human capital; and (b) the impact of e-commerce participation on the share of exports in total sales controlling for firms' age, size, foreign ownership, and human capital. The error bars refer to the 95 percent confidence intervals around the estimated coefficients. For Asia, the estimated coefficients imply that participation in e-commerce is associated with a 30 percent increase in total factor productivity and an increase in the share of exports to total sales by close to 2 units, corresponding to a 50 percent rise. ${ }^{* *} p<0.05 ;{ }^{* * *} p<0.01$.

Consistent with the earlier evidence, the potential impact of e-commerce on firm productivity seems to be greater in Asia than in other developing regions. In Asia, participation in e-commerce is associated with 30 percent higher TFP, double the overall figure.

Looking at another indicator of performance, export, which is less subject to measurement errors, support our main findings. ${ }^{9}$ E-commerce firms export a larger share of their total sales on average (Figure 12, Panel 2; and Table 2). On average, firms engaged in e-commerce export 40 percent more than other firms. As with the productivity level, the difference is even greater in Asia, where e-commerce firms export 50 percent more than other firms. This highlights the potential of e-commerce in promoting cross-border trade.

\footnotetext{
${ }^{9}$ The analysis of exports relies on a similar empirical model as in equation 2 , with the exception that the dependent variable is the share of exports in each firm's total sales.
} 
Table 2. E-commerce, Total Factor Productivity, and Export: Ordinary Least Squares 1/

\begin{tabular}{|c|c|c|c|c|c|c|c|c|}
\hline & \multicolumn{4}{|c|}{ Dependent variable: Total factor productivity } & \multicolumn{4}{|c|}{ Dependent variable: Share of exports in total sales } \\
\hline & \multicolumn{2}{|c|}{ All countries } & \multicolumn{2}{|c|}{ Asia } & \multicolumn{2}{|c|}{ All countries } & \multicolumn{2}{|c|}{ Asia } \\
\hline & (1) & (2) & (3) & (4) & (5) & (6) & (7) & (8) \\
\hline \multirow[t]{2}{*}{ E-commerce participation } & $0.151 * * *$ & $0.138 * * *$ & $0.296 * * *$ & $0.298 * * *$ & $2.348 * * *$ & $1.258 * * *$ & $3.233 * * *$ & $1.794 * *$ \\
\hline & $(0.0523)$ & $(0.0519)$ & $(0.0760)$ & $(0.0785)$ & $(0.338)$ & $(0.456)$ & $(0.744)$ & $(0.831)$ \\
\hline \multirow[t]{2}{*}{ Size (20-99 employees) } & & -0.0854 & & $-0.282 * *$ & & $2.289 * * *$ & & 0.718 \\
\hline & & $(0.0540)$ & & $(0.123)$ & & $(0.344)$ & & $(0.864)$ \\
\hline \multirow[t]{2}{*}{ Size ( $>=100$ employees) } & & $-0.257 * * *$ & & $-0.441 * * *$ & & $8.058 * * *$ & & $5.016 * * *$ \\
\hline & & $(0.0598)$ & & $(0.130)$ & & $(0.479)$ & & $(1.022)$ \\
\hline \multirow[t]{2}{*}{ Share of foreign capital } & & $0.00511 * * *$ & & 0.00283 & & $0.104 * * *$ & & $0.204 * * *$ \\
\hline & & $(0.000842)$ & & $(0.00202)$ & & $(0.00971)$ & & $(0.0419)$ \\
\hline \multirow[t]{2}{*}{ Age } & & $0.00375 * * *$ & & 0.00229 & & $-0.0333 * * *$ & & $-0.0849 * *$ \\
\hline & & $(0.00102)$ & & $(0.00453)$ & & $(0.0104)$ & & $(0.0399)$ \\
\hline \multirow[t]{2}{*}{ Share of export } & & 0.000858 & & 0.000264 & & & & \\
\hline & & $(0.000958)$ & & $(0.00152)$ & & & & \\
\hline \multirow[t]{2}{*}{ Share of high school graduates } & & $0.00607 * * *$ & & 0.00714 *** & & 0.00787 & & $0.0349 * *$ \\
\hline & & $(0.000769)$ & & $(0.00142)$ & & $(0.00646)$ & & $(0.0151)$ \\
\hline \multirow[t]{2}{*}{ Constant } & 0.337 & -0.244 & 2.562 * & $-0.301 * *$ & $6.076 * * *$ & $-6.385 * * *$ & $4.112 * * *$ & $3.59 * * *$ \\
\hline & $(0.676)$ & $(0.505)$ & $(1.334)$ & $(0.141)$ & $(1.119)$ & $(1.436)$ & $(1.371)$ & $(1.176)$ \\
\hline Observations & 4,749 & 4,535 & 1,198 & 1,156 & 18,671 & 12,240 & 2,953 & 2,546 \\
\hline Country dummies & Yes & Yes & Yes & Yes & Yes & Yes & Yes & Yes \\
\hline Sector dummies & Yes & Yes & Yes & Yes & Yes & Yes & Yes & Yes \\
\hline
\end{tabular}

\section{Addressing Potential Endogeneity}

The results presented in this paper could suffer from endogeneity bias due to reverse causation, measurement errors, or omitted variables. For instance, more productive or efficient firms can be those engaging proportionally more in e-commerce. While regular determinants of firm-level productivity are controlled for, unobservable characteristics at the firm level can still drive the adoption of e-commerce. Lastly, the e-commerce participation variable may suffer from measurement issues as firms with access to e-commerce may not actually use it because of other constraints. For example, the lack of reliable access to electricity, telecommunications, and transport infrastructure, all essential elements for a properly functioning e-commerce system, may inhibit the regular use of e-commerce and reduce its potential impact.

An instrumental variable approach is adopted to assess the robustness of the main results using three enabling factors for the adoption and use of e-commerce as instruments. More specifically, the instruments defined are the country-region averages of small firms' sentiment as to how (1) electricity, (2) telecommunications, and (3) transport represent obstacles to their operations. ${ }^{10}$ Using averages for only small firms can improve the exogeneity of the instruments, as larger firms may be better able to self-select their location into regions with a friendlier investment climate (Dollar, Hallward-Driemeier, and Mengistae 2005; Lall and Mengistae 2005). That said, it could also be possible that firms that

\footnotetext{
${ }^{10}$ In the case of export performance, the set of instruments is complemented with a fourth indicator to capture the ease to export from the region where the firm is operating.
} 
did not adopt e-commerce do not share the same perception of the investment climate as those we did. The tests of overidentifying restrictions confirm that the instruments are valid and correctly excluded from the estimated equation.

The instrumental variables approach using the two-stage least squares (2SLS) and the generalized method of moments (GMM) confirms the main results. ${ }^{11}$ Firms engaged in e-commerce are more productive than other firms, and the productivity difference is greater in Asia. Interestingly, the size of the coefficient associated with e-commerce is higher with the instrumental variable approach than the ordinary least squares approach, suggesting the existence of endogeneity through measurement errors. Firms engaged in e-commerce could have a productivity level that is up to two times larger than the level of other firms, particularly in Asia, when elements (such as reliable electricity, telecommunication, and transport) that facilitate the regular use of e-commerce are in place. ${ }^{12} \mathrm{With}$ respect to exports, the use of instrumental variables also magnifies the effect of e-commerce, but the larger effect is only significant in Asia.

The higher and always significant effect in Asia could reflect the fact that many countries in the region have greater potential for leapfrogging because they are home to a sizable middle-class with purchasing power that can effectively take advantage of better access and availability of goods through e-commerce. To test this hypothesis, countries with relatively low per capita income and small population size are excluded by way of restricting the sample to countries with a population of at least 10 million and per capita income of at least US $\$ 1,500 .{ }^{13}$ The results confirm the prior that the availability of a large population with a certain purchasing power could magnify the positive impact of e-commerce on firm productivity (see Appendix Table 4).

\footnotetext{
11 The results are also robust to the use of an alternative instrumental variable estimator, the limited information maximum likelihood, which tends to be efficient when errors are normally distributed.

12 The impact of e-commerce participation may vary depending on the sector. For instance, e-commerce may have a larger impact on retail than on more traditional sectors such as mineral production. In addition, variables related to access to reliable electricity, telecommunications, and transport infrastructure may directly impact firm productivity. An alternative set of instruments that is defined is the cross-term between the instruments defined above and the sector in which each firm operates. Firms' access to reliable electricity, telecommunications, and transport infrastructure is also directly controlled for. The results (see Appendix Table 4) confirm the main result: in Asia, firms engaged in e-commerce are significantly more productive than other firms.

13 The cut-off is applied using data for 2012, the year of the latest survey in the sample.
} 
Table 3. E-commerce, Total Factor Productivity, and Export: Instrumental Variable Approach 1/

\begin{tabular}{|c|c|c|c|c|c|c|c|c|}
\hline & \multicolumn{4}{|c|}{ Dependent Variable: Total Factor Productivity } & \multicolumn{4}{|c|}{ Dependent Variable: Share of Exports in Total Sales } \\
\hline & \multicolumn{2}{|c|}{ IV-2SLS } & \multicolumn{2}{|c|}{ IV-GMM } & \multicolumn{2}{|c|}{ IV-2SLS } & \multicolumn{2}{|c|}{ IV-GMM } \\
\hline & $\begin{array}{l}\text { All countries } \\
\text { (1) }\end{array}$ & $\begin{array}{c}\text { Asia } \\
\text { (2) }\end{array}$ & $\begin{array}{c}\text { All countries } \\
\text { (3) }\end{array}$ & $\begin{array}{l}\text { Asia } \\
\text { (4) }\end{array}$ & $\begin{array}{l}\text { All countries } \\
\text { (5) }\end{array}$ & $\begin{array}{c}\text { Asia } \\
\text { (6) }\end{array}$ & $\begin{array}{c}\text { All countries } \\
\text { (7) }\end{array}$ & $\begin{array}{c}\text { Asia } \\
\text { (8) }\end{array}$ \\
\hline E-commerce participation & $\begin{array}{l}\mathbf{0 . 8 2 1} \\
(0.476)\end{array}$ & $\begin{array}{l}\mathbf{1 . 0 1 5} \text { *** } \\
(0.387)\end{array}$ & $\begin{array}{l}\mathbf{0 . 8 2 5} \text { * } \\
(0.476)\end{array}$ & $\begin{array}{l}1.015 \text { *** } \\
(0.387)\end{array}$ & $\begin{array}{r}9.147 \\
(8.270)\end{array}$ & $\begin{array}{l}8.992 \text { * } \\
(5.091)\end{array}$ & $\begin{array}{r}10.12 \\
(8.137)\end{array}$ & $\begin{array}{l}10.33 \text { ** } \\
(4.970)\end{array}$ \\
\hline Size (20-99 employees) & $\begin{array}{l}-0.153 \text { ** } \\
(0.0733)\end{array}$ & $\begin{array}{l}-0.403 \text { ** } \\
(0.159)\end{array}$ & $\begin{array}{l}-0.155 \text { ** } \\
(0.0733)\end{array}$ & $\begin{array}{l}-0.403 \text { ** } \\
(0.159)\end{array}$ & $\begin{array}{l}3.7411^{* * *} \\
(0.686)\end{array}$ & $\begin{array}{r}1.807 \\
(1.443)\end{array}$ & $\begin{array}{l}3.683^{* * *} \\
(0.683)\end{array}$ & $\begin{array}{r}1.564 \\
(1.439)\end{array}$ \\
\hline Size ( > =100 employees) & $\begin{array}{l}-0.369^{* * *} \\
(0.0895)\end{array}$ & $\begin{array}{l}-0.694 \text { *** } \\
(0.187)\end{array}$ & $\begin{array}{l}-0.369 * * * \\
(0.0895)\end{array}$ & $\begin{array}{l}-0.694 \text { *** } \\
(0.187)\end{array}$ & $\begin{array}{l}11.48^{* * \star} \\
(0.962)\end{array}$ & $\begin{array}{l}7.671^{* * *} \\
(2.047)\end{array}$ & $\begin{array}{l}11.45^{* * *} \\
(0.950)\end{array}$ & $\begin{array}{l}6.912 \text { *** } \\
(1.986)\end{array}$ \\
\hline Share of foreign capital & $\begin{array}{l}0.00577^{* * *} \\
(0.00101)\end{array}$ & $\begin{array}{r}0.00323 \\
(0.00228)\end{array}$ & $\begin{array}{l}0.00577^{* * *} \\
(0.00101)\end{array}$ & $\begin{array}{r}0.00325 \\
(0.00227)\end{array}$ & $\begin{array}{l}0.1444^{* \star *} \\
(0.0140)\end{array}$ & $\begin{array}{l}0.202 \text { *** } \\
(0.0464)\end{array}$ & $\begin{array}{l}0.144 \text { *** } \\
(0.0140)\end{array}$ & $\begin{array}{l}0.203 \text { *** } \\
(0.0464)\end{array}$ \\
\hline Age & $\begin{array}{l}0.00449 \text { *** } \\
(0.00126)\end{array}$ & $\begin{array}{l}-0.00200 \\
(0.00496)\end{array}$ & $\begin{array}{l}0.00454 \text { *** } \\
(0.00126)\end{array}$ & $\begin{array}{l}-0.00196 \\
(0.00495)\end{array}$ & $\begin{array}{l}-0.066 \text { *** } \\
(0.0144)\end{array}$ & $\begin{array}{l}-0.0931 \\
(0.0575)\end{array}$ & $\begin{array}{l}-0.0691 \text { *** } \\
(0.0144)\end{array}$ & $\begin{array}{l}-0.0984 \text { * } \\
(0.0579)\end{array}$ \\
\hline Share of export & $\begin{array}{l}-0.000192 \\
(0.00120)\end{array}$ & $\begin{array}{l}0.000573 \\
(0.00193)\end{array}$ & $\begin{array}{r}-0.000242 \\
(0.00120)\end{array}$ & $\begin{array}{l}0.000555 \\
(0.00193)\end{array}$ & & & & \\
\hline Share of high school graduates & $\begin{array}{l}0.00555 \text { *** } \\
(0.00106)\end{array}$ & $\begin{array}{l}0.00433 \text { ** } \\
(0.00184)\end{array}$ & $\begin{array}{l}0.00553 \text { *** } \\
(0.00106)\end{array}$ & $\begin{array}{l}0.00435^{* *} \\
(0.00183)\end{array}$ & $\begin{array}{l}-0.0134 \\
(0.0123)\end{array}$ & $\begin{array}{l}0.00922 \\
(0.0228)\end{array}$ & $\begin{array}{r}-0.0149 \\
(0.0122)\end{array}$ & $\begin{array}{l}0.00438 \\
(0.0225)\end{array}$ \\
\hline Access to finance dummy & $\begin{array}{l}0.178 \text { *** } \\
(0.0652)\end{array}$ & $\begin{array}{l}0.0595 \\
(0.106)\end{array}$ & $\begin{array}{l}0.178 \text { *** } \\
(0.0652)\end{array}$ & $\begin{array}{l}0.0595 \\
(0.106)\end{array}$ & $\begin{array}{l}-0.410 \\
(0.631)\end{array}$ & $\begin{array}{l}-1.619 \\
(1.270)\end{array}$ & $\begin{array}{r}-0.379 \\
(0.630)\end{array}$ & $\begin{array}{l}-1.704 \\
(1.268)\end{array}$ \\
\hline R\&D dummy & $\begin{array}{r}0.0498 \\
(0.0557)\end{array}$ & $\begin{array}{r}0.0932 \\
(0.0922)\end{array}$ & $\begin{array}{r}0.0522 \\
(0.0556)\end{array}$ & $\begin{array}{r}0.0959 \\
(0.0903)\end{array}$ & $\begin{array}{l}1.233 \text { * } \\
(0.677)\end{array}$ & $\begin{array}{r}1.185 \\
(1.287)\end{array}$ & $\begin{array}{c}1.12 \text { * } \\
(0.674)\end{array}$ & $\begin{array}{r}1.276 \\
(1.270)\end{array}$ \\
\hline Constant & $\begin{array}{l}-1.512 \text { *** } \\
(0.435)\end{array}$ & $\begin{array}{l}-0.597 \\
(0.261)\end{array}$ & $\begin{array}{l}-1.514 \text { *** } \\
(0.435)\end{array}$ & $\begin{array}{l}-0.6 \text { ** } \\
(0.260)\end{array}$ & $\begin{array}{r}-7.930 \\
(5.789)\end{array}$ & $\begin{array}{l}-2.129 \\
(2.736)\end{array}$ & $\begin{array}{r}-8.360 \\
(5.709)\end{array}$ & $\begin{array}{r}-2.520 \\
(2.727)\end{array}$ \\
\hline Test of overidentifying restriction & & & & & & & & \\
\hline Score / Hansen's J & 0.72 & 0.02 & 0.72 & 0.02 & 4.34 & 4.67 & 4.34 & 4.67 \\
\hline$p$-value & 0.70 & 0.99 & 0.70 & 0.99 & 0.23 & 0.20 & 0.23 & 0.20 \\
\hline Observations & 2,891 & 824 & 2,891 & 824 & 7,286 & 1,538 & 7,286 & 1,538 \\
\hline Country dummies & Yes & Yes & Yes & Yes & Yes & Yes & Yes & Yes \\
\hline Sector dummies & Yes & Yes & Yes & Yes & Yes & Yes & Yes & Yes \\
\hline
\end{tabular}

$1 /$ The reference for size dummies is small size ( $<20$ employees). The estimations of productivity also control for the share of informal payments, to capture the quality of local institutions, but the associated coefficients are not significant. Robust standard errors in parentheses. ${ }^{* * *} p<0.01,{ }^{* *} p<0.05,{ }^{*} p<0.1$.

\section{B. The Role of Platforms}

The section above analyzed the impact of e-commerce on firm performance without distinguishing the specific role of platforms. ${ }^{14}$ Platforms can magnify the benefits of e-commerce, but they raise competition issues. Platforms can create positive externalities, including through network effects (Figure 13), and they have great potential to amplify the economic benefits of e-commerce. In addition to increased competition within the market and pressure to lower prices, including through reduced search costs, a broader geographical reach of suppliers, and savings in supply chain management, platforms bring about additional advantages through various network effects. A recent report by the Hinrich Foundation (2019) highlights that about 12 percent of global goods trade is now conducted via international e-commerce, with much of it driven by platforms such as Alibaba, Amazon, eBay, Flipkart, and Rakuten.

\footnotetext{
${ }^{14}$ Platforms in this context can be defined as a technology solution that allows businesses or customers to buy or sell products and services online. Platforms often bring together many businesses and customers and offer services to them, including delivery systems and customer services.
} 
As illustrated in the section above, firms with online activities also have better access to finance. For instance, Ant Financial Services Group, an affiliate company of the Chinese Alibaba group, collects information from Taobao, an e-commerce platform that is a subsidiary of Alibaba, to extend the credit frontier to firms not served by traditional banks. By enabling small and medium-sized enterprises to access advanced information and communications technology infrastructure, data centers, applications, and processes usually available to the most productive firms, platforms can further help firms boost their productivity. For example, Flipkart, a leading e-commerce platform in India, adopted several innovative initiatives to break barriers in e-commerce accessibility and affordability. Flipkart empowered its merchants through various types of training, including on account management, marketing, and warehousing. The company also put in place a dedicated supply chain and last-mile infrastructure to facilitate delivery and developed a light e-commerce application that functions with limited Internet bandwidth or offline. A higher number of providers or customers using a platform tends to enhance its efficiency, including through the use of big data to better customize products and services, which in turn attracts more providers and customers (same-side network effect). Overall, the development of platforms has brought benefits to consumers and merchants, but it also comes with some challenges. ${ }^{15}$

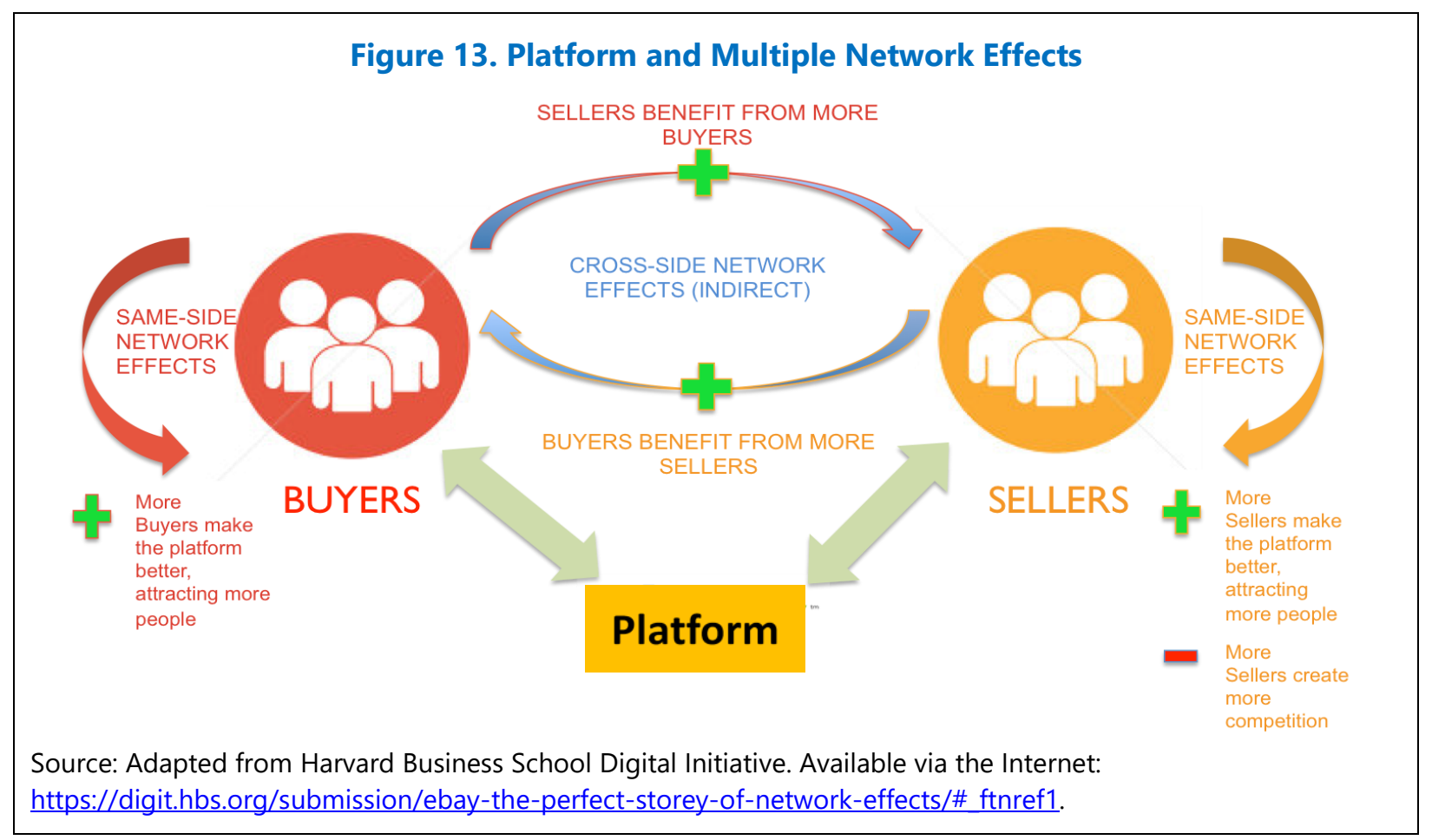

\footnotetext{
15 Platforms can raise competition issues. Exclusive access to information of platforms poses anti-competitive concerns, particularly when e-commerce platforms become large. Network effects also make it challenging for retailers and vendors to switch platforms, reinforcing their market power and exacerbating the risk of anticompetitive practices.
} 


\section{Enabling Factors: Significant Growth Potential for E-commerce in Asia}

There is room to improve enabling factors to further boost e-commerce in Asia. Existing digital divides and gaps in key infrastructure and e-commerce legislation are still preventing many Asian economies from fully reaping the potential benefits.

\section{Economic Factors and Conditions}

A successful e-commerce transaction requires several critical elements, including Internet access to allow the user to place an order; secure Internet servers to safeguard payments and personal information; a payment method such as a credit card, e-wallet, or mobile payment; and reliable delivery services for physical goods. While advanced economies, including in Asia, have high readiness for e-commerce, emerging and developing economies in the region are not as ready, with many economies still having sizable gaps. For instance, less than 40 percent of individuals (aged 15+) have a financial account in Nepal, Bhutan, Bangladesh, Lao PDR, Myanmar, and Cambodia (Figure 14). In many of these countries, less than 30 percent of individuals use the Internet. Gaps in postal and delivery systems in many countries also represent important bottlenecks, particularly for cross-border e-commerce.

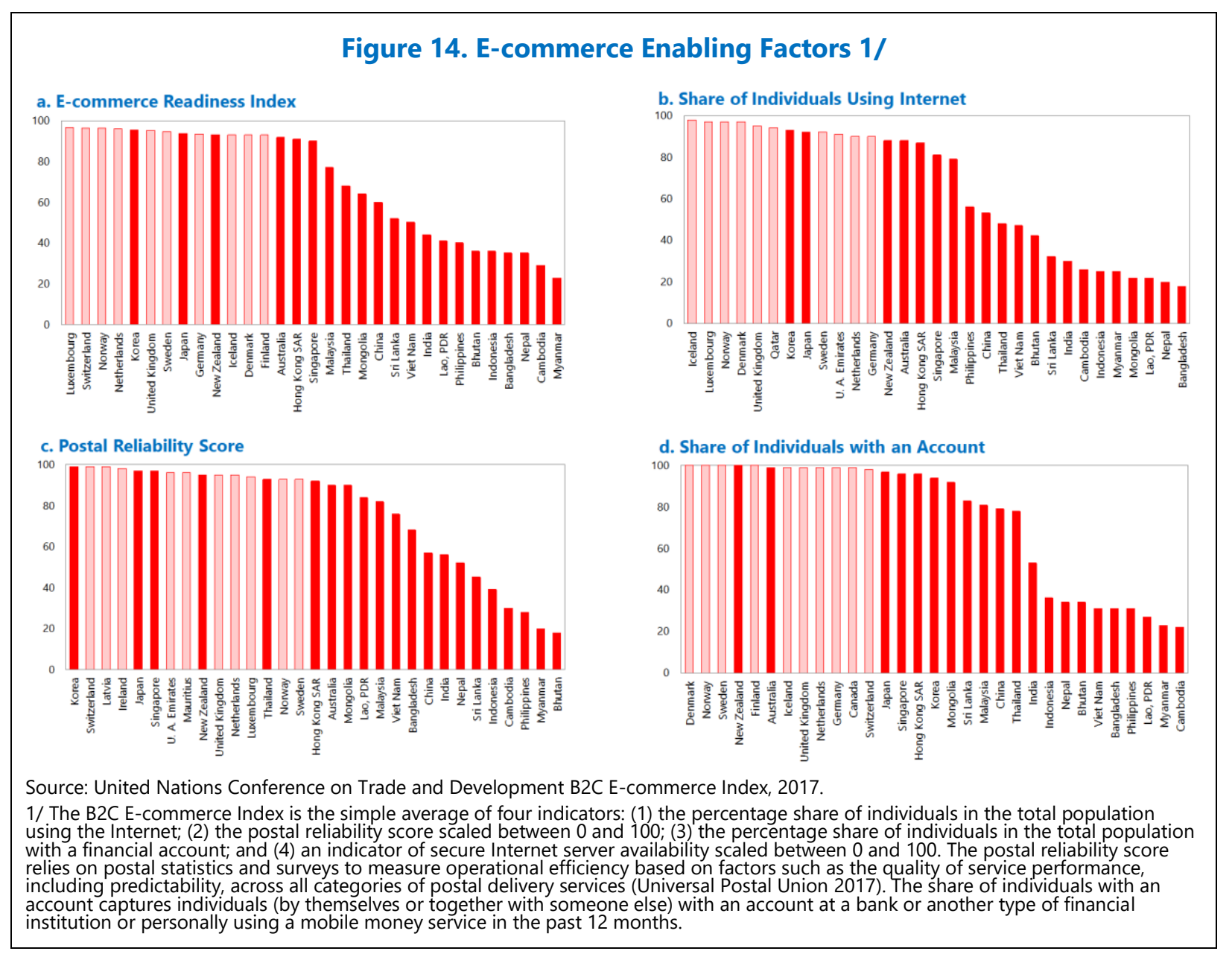




\section{Legal and Institutional Environment}

The absence of laws to regulate the e-environment inhibits participation in e-commerce both for consumers and suppliers. For instance, e-transaction laws are essential to make electronic forms of exchange legally equivalent to paper-based transactions, a critical condition for most e-commerce transactions. A lack of consumer protection laws and legislation on privacy, data protection, and cybercrime may prevent potential customers from shopping online. ${ }^{16}$ While all advanced Asian economies and most emerging and developing economies in the region benefit from legislation covering electronic transactions, consumer protection, data protection, and cybercrime, this legislation is practically nonexistent in Pacific island countries (Figure 15; see also Appendix Table 5). Enacting appropriate legislative and regulatory mechanisms can lower legal barriers to the use of e-commerce, raise consumer confidence, and expand domestic and, particularly, cross-border transactions. In addition to enacting laws, establishing enforcement mechanisms, including the capacity to address anticompetitive

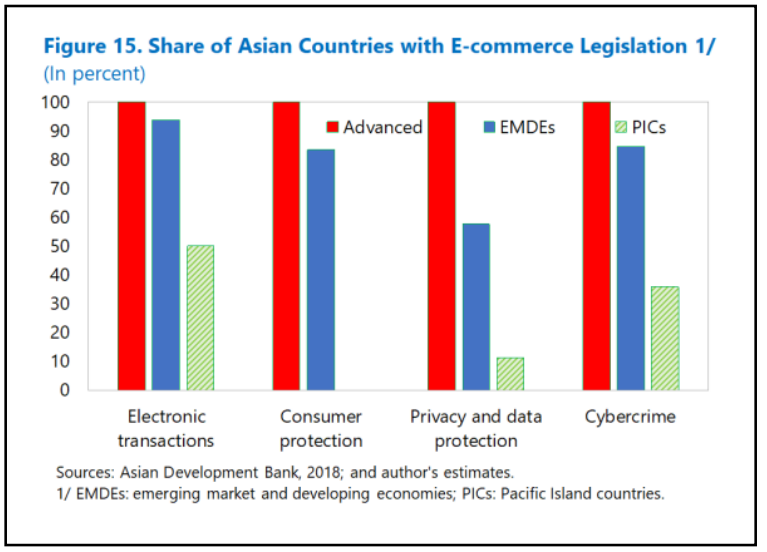
practices, is important to support the development of e-commerce.

\section{Conclusion}

This paper has investigated the potential of e-commerce as a new growth engine in Asia. The use of e-commerce has accelerated in recent years, supported by the global digital revolution. Asia, led by China, has been playing a leading role. From less than 1 percent about a decade ago, China's share in global e-commerce retail transactions has exploded to more than 40 percent. The rapid rise of e-commerce in Asia is not limited to China. Other Asian economies such as India and Indonesia have also been experiencing strong growth rates in e-commerce sales that exceeded 20 percent in 2017 alone.

E-commerce offers unprecedented opportunities to businesses, consumers, and the economy at large. Using firm-level data for a large sample of developing economies, including six Asian economies, this paper investigated how firms engaged in online commerce differ from other firms, with a focus on productivity and exports. The results show that participation in online commerce is associated with 14 percent higher total factor productivity at the firm level. In Asia, participation in e-commerce is associated with more than 30 percent higher total factor productivity, twice the overall figure. The results also highlight that firms

\footnotetext{
${ }^{16}$ For instance, the 2017 Norton Cyber Security Insights Report, highlights that 186.4 million people in India were cybercrime victims, costing the economy a sizable US\$18.5 billion in 2017 (Symantec 2018).
} 
engaged in e-commerce export 40 percent more than other firms. As with the productivity level, the difference is even greater in Asia, where e-commerce firms export 50 percent more, highlighting the potential of e-commerce to promote cross-border trade.

The results are robust to the use of an instrumental variable approach, which highlights that the potential effect of e-commerce on productivity and exports in Asia could be larger in the presence of reliable electricity, telecommunication, and transport infrastructure, essential elements for its effective use. The availability of a large population with some purchasing power also has the potential to amplify the positive impact of e-commerce on firm productivity. E-commerce platforms can magnify the potential benefits of e-commerce through various network effects, but they also raise competition issues, particularly when the platforms become large.

Despite rapid growth in recent years, still-limited e-shopper penetration in many Asian economies indicates that there is room to further expand e-commerce. Existing digital divides and gaps in key infrastructure such as Internet penetration, delivery logistics, and access to financial accounts, as well as limits in e-commerce legislation, are still preventing many Asian economies from fully reaping the potential benefits. Removing these barriers would further boost e-commerce, supporting international trade, creating more opportunities for businesses, and increasing consumers' welfare. 


\section{Box 1. E-commerce in Indonesia}

Indonesia has witnessed tremendous growth of online commerce in recent years, supported by a vibrant digital ecosystem and a growing youth population that is digitally savvy and constitutes a sizable customer base for the digital economy. Between 2014 and 2017, the share of online sales in total retail sales increased fourfold, from less than 1 percent to about 3 percent (Figure 1.1). Online sales increased by more than 20 percent just in 2017 over the previous year.

Supporting this rapid growth, the numbers of users of the mobile Internet and digital payments have exploded in recent years (Figure 1.2). Between 2015 and 2017, the number of mobile Internet users increased by about 21 percent. While the size of the bandwidth per user and the average connection speed may be low compared to peers, mobile data are cheap in Indonesia at about half the price of peer countries that are members of the Association of Southeast Asian Nations (ASEAN). The share of digitally active users in the banked population also increased rapidly between 2014 and 2017, with the average consumer making more transactions via smartphone than three years ago.

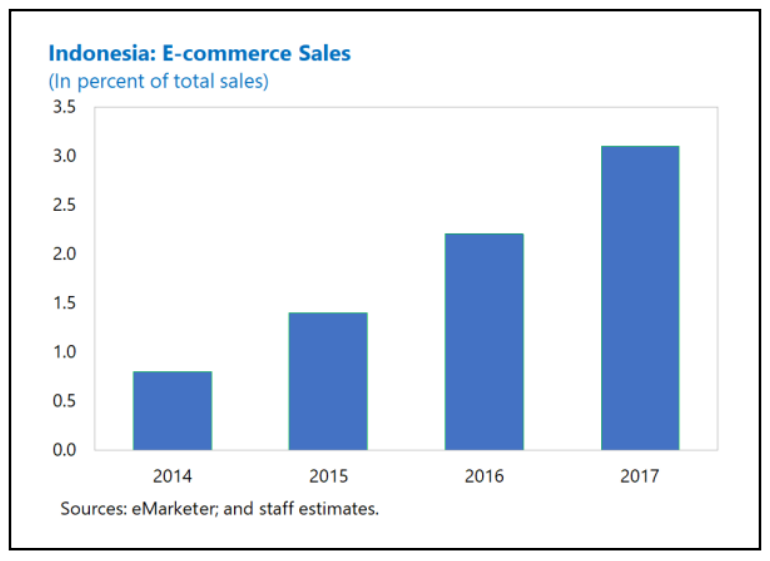

As the analysis in the paper has highlighted, firms engaged in online commerce in Asia, including Indonesia, are at least 30 percent more productive and export at least 50 percent more on average. E-commerce platforms can magnify this effect. A study by McKinsey shows that shopping online helps consumers in non-Java regions save between 11 and 25 percent (Das and others 2018). With up to 35 percent of online revenue generated by women, compared to 15 percent for offline retail, ecommerce can help promote social equality by lowering the persistent gender gap. McKinsey projects that by 2022 , online commerce will directly or indirectly support about 26 million jobs, compared with 4 million currently.

Yet, Indonesia faces a digital divide and gaps in various factors that are often associated with a thriving online commerce sector. For instance, with only a quarter of the overall population using the Internet, Indonesia has one of the lowest Internet penetration rates in the ASEAN region. The country also has one of the lowest postal reliability scores and a large share of unbanked population relying mostly on cash. Indonesia's logistics infrastructure lags its regional peers, ranking 63rd out of 160 countries globally in 2016 with issues related to both insufficient coverage and inconsistent service quality (see the World Bank's Logistics Performance Index). With only about half of the population having access to financial services, Indonesia lags regional benchmarks such as Malaysia and Thailand, where more than 80 percent of the population has access to financial services. Cyber-risk is also a serious concern and could act as a disincentive to online commerce.

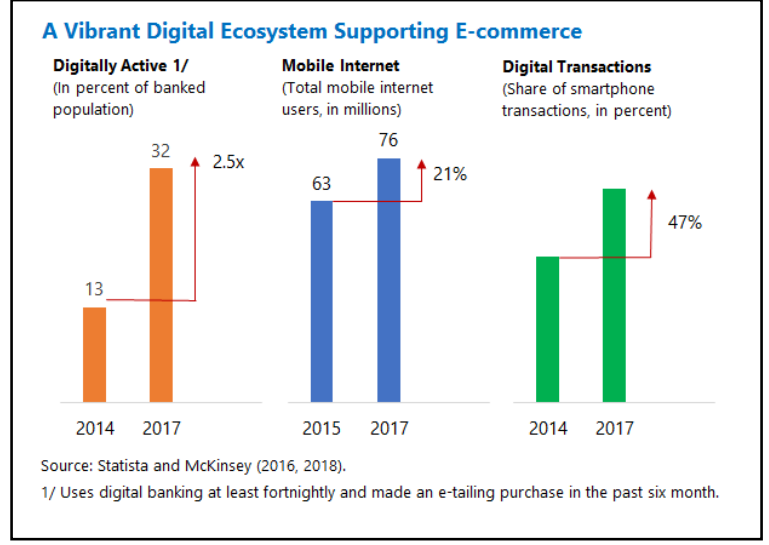

To help Indonesia overcome the challenges it faces with online commerce, priority actions would include expanding the quality Internet coverage (including in rural areas) to reduce the digital divide; expanding reliable logistics infrastructure for pickups and deliveries; leveraging the rise of e-commerce to further expand cashless payments and support lending, especially to smaller enterprises; enhancing human capital to meet the demand of talent from the emerging digital sector; and encouraging SMEs to go online, in particular through online marketplaces. Large marketplaces could also provide various benefits to SMEs, including marketing analytics, inventory management, and access to credit, which could enhance productivity and provide export opportunities. Addressing these issues will help Indonesia fully expand its online commerce and truly harness its benefits. The Indonesian authorities have started to implement various measures to support the rise of ecommerce. These include expanding logistics infrastructure through the National Logistic System Development and ASEAN Logistic Service Integration; improving the quality of internet coverage through the Palapa Ring Project; enhancing human capital through the Digital Talent Scholarship Program; and encouraging SMEs to go online through the on-Boarding SME program. 


\begin{tabular}{|c|c|c|c|c|}
\hline \multicolumn{5}{|c|}{ Appendix Table 1. Country List } \\
\hline Asia & $\begin{array}{l}\text { Eastern and Central } \\
\text { Europe }\end{array}$ & $\begin{array}{l}\text { Latin America and } \\
\text { Caribbean }\end{array}$ & $\begin{array}{l}\text { Middle East, North Africa, } \\
\text { and Central Asia }\end{array}$ & Sub-Saharan Africa \\
\hline China & Albania & Argentina & Afghanistan & Angola \\
\hline Indonesia & Belarus & Bolivia & Armenia & Botswana \\
\hline Mongolia & Bosnia and Herzegovina & Brazil & Azerbaijan & Burkina Faso \\
\hline Nepal & Bulgaria & Chile & Georgia & Burundi \\
\hline Philippines & Croatia & Colombia & Iraq & Cameroon \\
\hline \multirow[t]{17}{*}{ Vietnam } & Czech Republic & Costa Rica & Kazakhstan & Côte d'Ivoire \\
\hline & Estonia & Dominican Republic & Kyrgyz Republic & D. R. of Congo \\
\hline & Macedonia & Ecuador & Mauritania & Ethiopia \\
\hline & Hungary & El Salvador & Pakistan & Ghana \\
\hline & Kosovo & Guatemala & Tajikistan & Guinea Bissau \\
\hline & Latvia & Honduras & Uzbekistan & Madagascar \\
\hline & Lithuania & Jamaica & Yemen & Mali \\
\hline & Moldova & Mexico & & Mauritius \\
\hline & Montenegro & Nicaragua & & Mozambique \\
\hline & Poland & Panama & & Senegal \\
\hline & Romania & Paraguay & & South Africa \\
\hline & Russia & Peru & & Zambia \\
\hline & Serbia & Trinidad and Tobago & & \\
\hline & Slovak Republic & Uruguay & & \\
\hline & Slovenia & Venezuela & & \\
\hline & Turkey & & & \\
\hline & Ukraine & & & \\
\hline
\end{tabular}

Appendix Table 2. Estimation of Total Factor Productivity 1/

\begin{tabular}{lccc}
\hline & & Log (Value added) & Non-Asia \\
\cline { 2 - 4 } & All & Asia & $(3)$ \\
\hline Log(Capital) & $(1)$ & $(2)$ & $0.25 * * *$ \\
& $0.262^{* * *}$ & $0.324^{* * *}$ & $(0.00947)$ \\
Log(Labor) & $(0.00867)$ & $(0.0221)$ & $0.949 * * *$ \\
& $0.936^{* * *}$ & $0.871 * * *$ & $(0.0148)$ \\
Constant & $(0.0133)$ & $(0.0306)$ & $5.568 * *$ \\
& $5.486^{* * *}$ & $3.484 * * *$ & $(0.363)$ \\
\hline Observations & $(0.361)$ & $(0.296)$ & 13,947 \\
Country dummies & 16,674 & 2,727 & Yes \\
Sector dummies & Yes & Yes & Yes \\
R-squared & Yes & Yes & 0.702 \\
\hline
\end{tabular}

1/ Robust standard errors in parentheses *** $p<0.01,{ }^{* *} p<0.05,{ }^{*} p<0.1$ 
Appendix Table 3. E-commerce, Total Factor Productivity, and Exports: Instrumental Variable Approach with the Limited Information Maximum Likelihood (LIML) Estimator 1/

\begin{tabular}{|c|c|c|c|c|}
\hline & \multicolumn{2}{|c|}{$\begin{array}{c}\text { Dependent Variable: Total Factor } \\
\text { Productivity }\end{array}$} & \multicolumn{2}{|c|}{$\begin{array}{c}\text { Dependent Variable: Share of } \\
\text { Exports in Total Sales }\end{array}$} \\
\hline & All countries & Asia & All countries & Asia \\
\hline & IV-LIML & IV-LIML & IV-LIML & IV-LIML \\
\hline & $(1)$ & $(2)$ & (3) & (4) \\
\hline \multirow[t]{2}{*}{ E-commerce participation } & $0.829 *$ & $1.015 * *$ & 9.798 & 9.438 * \\
\hline & $(0.477)$ & $(0.407)$ & $(8.746)$ & $(5.560)$ \\
\hline \multirow[t]{2}{*}{ Size (20-99 employees) } & $-0.154 * \star$ & $-0.403 * * *$ & $3.708 * * \star$ & 1.737 \\
\hline & $(0.0725)$ & $(0.153)$ & $(0.800)$ & (1.988) \\
\hline \multirow[t]{2}{*}{ Size (>=100 employees) } & $-0.37 * \star \star$ & $-0.694 * * *$ & $11.43 * * \star$ & $7.566 * * *$ \\
\hline & $(0.0864)$ & $(0.178)$ & $(0.952)$ & $(2.257)$ \\
\hline \multirow[t]{2}{*}{ Share of foreign capital } & $0.00577 * * *$ & 0.00323 & $0.144 * * *$ & $0.202 * * *$ \\
\hline & $0.000951)$ & $(0.00224)$ & $(0.00966)$ & $(0.0294)$ \\
\hline \multirow[t]{2}{*}{ Age } & $0.00449 * * *$ & -0.00200 & $-0.0661 * * \star$ & -0.0929 \\
\hline & $(0.00133)$ & $(0.00520)$ & $(0.0136)$ & $(0.0705)$ \\
\hline \multirow[t]{2}{*}{ Share of export } & -0.000191 & 0.000573 & & \\
\hline & $(0.00111)$ & $(0.00213)$ & & \\
\hline \multirow[t]{2}{*}{ Share of high school graduates } & $0.00554 * * *$ & 0.00433 ** & -0.0140 & 0.00851 \\
\hline & $(0.00102)$ & $(0.00176)$ & $(0.0124)$ & $(0.0219)$ \\
\hline \multirow[t]{2}{*}{ Access to finance dummy } & 0.178 *** & 0.0595 & -0.426 & -1.634 \\
\hline & $(0.0628)$ & $(0.107)$ & $(0.643)$ & $(1.281)$ \\
\hline \multirow[t]{2}{*}{ Share of informal payment } & 0.00127 & 0.0431 & & \\
\hline & $(0.0110)$ & $(0.0340)$ & & \\
\hline \multirow[t]{2}{*}{ R\&D dummy } & 0.0494 & 0.0932 & 1.199 * & 1.161 \\
\hline & $(0.0564)$ & $(0.0993)$ & $(0.696)$ & $(1.241)$ \\
\hline \multirow[t]{2}{*}{ Constant } & $-1.518 * * *$ & $-0.597 * \star$ & -8.375 & -2.335 \\
\hline & $(0.471)$ & $(0.248)$ & (6.203) & (3.224) \\
\hline \multicolumn{5}{|l|}{ Test of overidentifying restrictions } \\
\hline Anderson-Rubin & 0.67 & 0.02 & 3.99 & 4.90 \\
\hline$p$-value & 0.72 & 0.99 & 0.26 & 0.18 \\
\hline Basmann F & 0.33 & 0.01 & 1.32 & 1.62 \\
\hline$p$-value & 0.72 & 0.99 & 0.26 & 0.18 \\
\hline Observations & 2,891 & 824 & 7,286 & 1,538 \\
\hline Country dummies & Yes & Yes & Yes & Yes \\
\hline Sector dummies & Yes & Yes & Yes & Yes \\
\hline
\end{tabular}

1/ The reference for size dummies is small size (<20 employees). The estimations of productivity also control for the share of informal payments, to capture the quality of local institutions, but the associated coefficients are not significant. Standard errors in parentheses. ${ }^{* *} p<0.01,{ }^{* *} p<0.05,{ }^{*} p<0.1$. 
Appendix Table 4. E-commerce, Total Factor Productivity, and Exports: Alternative Instruments and Sub-sample of Middle-Income Countries 1/

\begin{tabular}{|c|c|c|c|c|}
\hline & \multicolumn{4}{|c|}{ Dependent Variable: Total Factor Productivity } \\
\hline & \multicolumn{2}{|c|}{$\begin{array}{l}\text { Alternative instrumentation } \\
\text { strategy }\end{array}$} & \multicolumn{2}{|c|}{$\begin{array}{l}\text { Sub-sample of large middle- } \\
\text { income countries }\end{array}$} \\
\hline & $\begin{array}{c}\mathrm{IV}-2 \mathrm{SLS} \\
(1)\end{array}$ & $\begin{array}{l}\text { IV-GMM } \\
\text { (2) }\end{array}$ & $\begin{array}{c}\text { IV-2SLS } \\
(3)\end{array}$ & $\begin{array}{c}\text { IV-GMM } \\
(4)\end{array}$ \\
\hline E-commerce participation & $\begin{array}{l}1.019 \text { ** } \\
(0.478)\end{array}$ & $\begin{array}{l}0.958 \text { ** } \\
(0.466)\end{array}$ & $\begin{array}{c}0.903 \text { * } \\
(0.533)\end{array}$ & $\begin{array}{l}\mathbf{0 . 9 1 4} \\
(0.531)\end{array}$ \\
\hline Obstacle to access electricity & $\begin{array}{r}-0.0167 \\
(0.0866)\end{array}$ & $\begin{array}{r}-0.00409 \\
(0.0845)\end{array}$ & & \\
\hline Obstacle to access transport & $\begin{array}{r}-0.116 \\
(0.0773)\end{array}$ & $\begin{array}{r}-0.117 \\
(0.0768)\end{array}$ & & \\
\hline Obstacle to access telecommunication & $\begin{array}{l}0.0952 \\
(0.136)\end{array}$ & $\begin{array}{r}0.106 \\
(0.131)\end{array}$ & & \\
\hline Size (20-99 em ployees) & $\begin{array}{l}-0.344 \text { ** } \\
(0.171)\end{array}$ & $\begin{array}{l}-0.335 * * \\
(0.167)\end{array}$ & $\begin{array}{l}-0.161 \text { * } \\
(0.0881)\end{array}$ & $\begin{array}{l}-0.163 \text { * } \\
(0.0879)\end{array}$ \\
\hline Size (>=100 employees) & $\begin{array}{l}-0.618 * * * \\
(0.215)\end{array}$ & $\begin{array}{l}-0.603 * \star * \\
(0.209)\end{array}$ & $\begin{array}{l}-0.326 * \star \star \\
(0.111)\end{array}$ & $\begin{array}{l}-0.326^{* \star \star} \\
(0.110)\end{array}$ \\
\hline Share of foreign capital & $\begin{array}{r}0.00332 \\
(0.00273)\end{array}$ & $\begin{array}{r}0.00355 \\
(0.00270)\end{array}$ & $\begin{array}{l}0.00597 * * * \\
(0.00119)\end{array}$ & $\begin{array}{l}0.00595 * * * \\
(0.00119)\end{array}$ \\
\hline Age & $\begin{array}{l}-0.00421 \\
(0.00520)\end{array}$ & $\begin{array}{l}-0.00469 \\
(0.00518)\end{array}$ & $\begin{array}{l}0.00428 \text { *** } \\
(0.00151)\end{array}$ & $\begin{array}{l}0.00431 * * * \\
(0.00151)\end{array}$ \\
\hline Share of export & $\begin{array}{r}0.00158 \\
(0.00233)\end{array}$ & $\begin{array}{c}0.000892 \\
(0.00224)\end{array}$ & $\begin{array}{l}0.000623 \\
(0.00158)\end{array}$ & $\begin{array}{l}0.000587 \\
(0.00158)\end{array}$ \\
\hline Share of high school graduates & $\begin{array}{l}0.0049 * * \\
(0.00213)\end{array}$ & $\begin{array}{l}0.00527 \text { ** } \\
(0.00210)\end{array}$ & $\begin{array}{l}0.00629 * * * \\
(0.00125)\end{array}$ & $\begin{array}{l}0.00627 * * * \\
(0.00125)\end{array}$ \\
\hline Access to finance dummy & $\begin{array}{r}0.104 \\
(0.120)\end{array}$ & $\begin{array}{l}0.0920 \\
(0.116)\end{array}$ & $\begin{array}{l}0.187^{* *} \\
(0.0785)\end{array}$ & $\begin{array}{c}0.186 \text { ** } \\
(0.0785)\end{array}$ \\
\hline$R \& D$ dummy & $\begin{array}{l}0.0959 \\
(0.112)\end{array}$ & $\begin{array}{r}0.115 \\
(0.108)\end{array}$ & $\begin{array}{r}0.0865 \\
(0.0682)\end{array}$ & $\begin{array}{r}0.0890 \\
(0.0681)\end{array}$ \\
\hline Constant & $\begin{array}{l}-0.594 \\
(0.372)\end{array}$ & $\begin{array}{l}-0.538 \\
(0.362)\end{array}$ & $\begin{array}{l}-1.701 \text { *** } \\
(0.495)\end{array}$ & $\begin{array}{l}-1.705^{* * *} \\
(0.495)\end{array}$ \\
\hline \multicolumn{5}{|l|}{ Test of overidentifying restrictions } \\
\hline Score / Hansen's J & 5.79 & 5.79 & 0.47 & 0.47 \\
\hline$p$-value & 0.89 & 0.89 & 0.79 & 0.79 \\
\hline Observations & 656 & 656 & 2,026 & 2,026 \\
\hline Country dummies & Yes & Yes & Yes & Yes \\
\hline Sector dummies & Yes & Yes & Yes & Yes \\
\hline \multicolumn{5}{|c|}{$\begin{array}{l}\text { 1/ The reference for size dummies is small size ( }<20 \text { employees). The estimations of productivity also control for } \\
\text { the share of informal payments to capture the quality of local institutions. The alternative instrumentation } \\
\text { strategy uses the cross-term between the instruments used before and sectoral dummies. The sub-sample } \\
\text { restricts the sample to countries with a population of at least } 10 \text { million and per capita income of at least } \\
\text { US } \$ 1,500 \text {. Robust standard errors in parentheses. }{ }^{* \star *} p<0.01,{ }^{* \star} p<0.05,{ }^{*} p<0.1 \text {. }\end{array}$} \\
\hline
\end{tabular}




\begin{tabular}{|c|c|c|c|c|}
\hline \multicolumn{5}{|c|}{ Appendix Table 5. Status of E-commerce Legislation in Asia and the Pacific 1/ } \\
\hline & Electronic Transactions & Consumer Protection & $\begin{array}{l}\text { Privacy and Data } \\
\text { Protection }\end{array}$ & Cybercrime \\
\hline \multicolumn{5}{|l|}{ Advanced economies (AEs) } \\
\hline Australia & $\diamond$ & $\diamond$ & $\diamond$ & $\diamond$ \\
\hline Hong Kong SAR & $\diamond$ & $\diamond$ & $\diamond$ & $\diamond$ \\
\hline Japan & $\diamond$ & 口 & 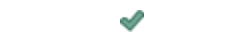 & $\diamond$ \\
\hline Korea & $\bullet$ & $\diamond$ & $\diamond$ & $\checkmark$ \\
\hline New Zealand & $\diamond$ & $\diamond$ & $\diamond$ & $\varnothing$ \\
\hline Taiwan Province of China & 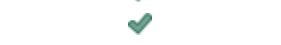 & 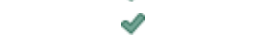 & $\diamond$ & $\diamond$ \\
\hline Singapore & 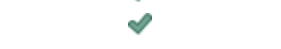 & $\bullet$ & 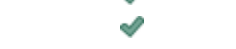 & 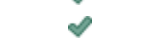 \\
\hline \multicolumn{5}{|c|}{$\begin{array}{l}\text { Emerging markets and developing } \\
\text { economies (EMDEs) }\end{array}$} \\
\hline Brunei Darussalam & $\bullet$ & 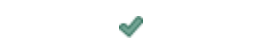 & $\approx$ & $\bullet$ \\
\hline Cambodia & $\triangle$ & $\Delta$ & $x$ & $\triangle$ \\
\hline China & 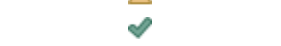 & 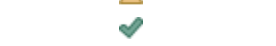 & 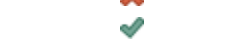 & 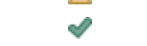 \\
\hline India & $\checkmark$ & x & $\checkmark$ & $\bullet$ \\
\hline Indonesia & $\bullet$ & $\bullet$ & $\bullet$ & $\varnothing$ \\
\hline Lao P.D.R. & 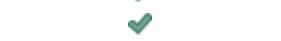 & $\triangle$ & $*$ & $x$ \\
\hline Malaysia & $\bullet$ & 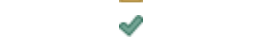 & $\bullet$ & $\varnothing$ \\
\hline Myanmar & $\bullet$ & $\bullet$ & $x$ & $\bullet$ \\
\hline Mongolia & $\bullet$ & 口 & 口 & $\varnothing$ \\
\hline Nepal & $\bullet$ & ロ & $\varnothing$ & $\varnothing$ \\
\hline Papua New Guinea & $\triangle$ & ロ & $x$ & $x$ \\
\hline Philippines & $\bullet$ & $\varnothing$ & 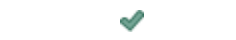 & $\varnothing$ \\
\hline Sri Lanka & 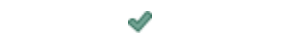 & 口 & 口 & $\varnothing$ \\
\hline Thailand & $\bullet$ & 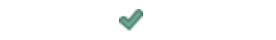 & $\triangle$ & $x$ \\
\hline Vietnam & $\bullet$ & $\varnothing$ & $\bullet$ & $\bullet$ \\
\hline \multicolumn{5}{|l|}{$\begin{array}{l}\text { Pacific island countries } \\
\text { and other small states }\end{array}$} \\
\hline Bhutan & $\bullet$ & $\varnothing$ & $\varnothing$ & 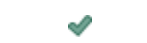 \\
\hline Fiji & $\varnothing$ & 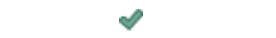 & 口 & $\varnothing$ \\
\hline Kiribati & $x$ & 口 & $x$ & $\varnothing$ \\
\hline Maldives & $x$ & ロ & $x$ & $x$ \\
\hline Marshall Islands & 口 & ロ & 口 & $\mathfrak{x}$ \\
\hline Micronesia & ロ & ロ & 口 & $\mathbf{x}$ \\
\hline Nauru & $\mathfrak{x}$ & 口 & x & $\mathfrak{x}$ \\
\hline Palau & 口 & ص & 口 & 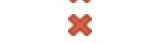 \\
\hline Samoa & $\bullet$ & ロ & x & $\mathfrak{x}$ \\
\hline Solomon Islands & x & ロ & x & $\ddot{x}$ \\
\hline Timor-Leste & $\square$ & ロ & 口 & $x$ \\
\hline Tonga & 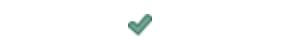 & 口 & $x$ & $\varnothing$ \\
\hline Tuvalu & $\mathfrak{x}$ & ロ & x & x \\
\hline Vanuatu & 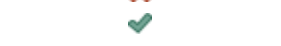 & 口 & $x$ & $x$ \\
\hline \multicolumn{5}{|c|}{ Source: Asia Development Bank, 2018.} \\
\hline \multirow[t]{2}{*}{$1 /$} & Legislation exists & $\Delta$ & Draft legislation & \\
\hline & Not available & $x$ & No legislation & \\
\hline
\end{tabular}




\section{REFERENCES}

Ackerberg, D.A., K. Caves, and G. Frazer, 2015, "Identification Properties of Recent Production Function Estimators," Econometrica, Vol. 83, Issue 6, pp. 2411-451.

Chaffai, Mohamed, Tidiane Kinda, and Patrick Plane, 2012, "Textile Manufacturing in Eight Developing Countries: Does Business Environment Matter for Firm Technical Efficiency?," The Journal of Development Studies, Vol. 48, Issue 10, pp. 1470-488.

Das, Kaushik, Toshan Tamhane, Ben Vatterott, Phillia Wibowo, and Simon Wintels, 2018, "The Digital Archipelago: How Online Commerce Is Driving Indonesia's Economic Development," McKinsey \& Company, August.

Dobbs, Richard, Yougang Chen, Gordon Orr, James Manyika, and Michael Chui, and Elsie Chang, 2013, "China's e-tail Revolution: Online Shopping as a Catalyst for Growth," McKinsey Global Institute, March.

Dolfen P., Einav L., P.J. Klenow, J.D. Levin, L. Levin, W. Best, 2019, Assessing the Gains from E-commerce, NBER Working Paper No. 25610 (Cambridge, Massachusetts: National Bureau of Economic Research).

Dollar, D., M. Hallward-Driemeier, and T. Mengistae, 2005, "Investment Climate and Firm Performance in Developing Economies," Economic Development and Cultural Change, Vol. 54, Issue 1, pp. 1-31.

eBay, 2016, Small Online Business Growth Report. Available via the Internet: https://www.ebaymainstreet.com/sites/default/files/ebay_global-report_2016-4_0.pdf.

Falk, Martin, and Eva Hagsten, 2015, "E-Commerce Trends and Impacts Across Europe," UNCTAD Discussion Paper No. 220. United Nations Conference on Trade and Development, Geneva.

Hinrich Foundation, 2019, "The Digital Komodo Dragon: How Indonesia Can Capture the Digital Trade Opportunity at Home and Abroad." Available via the Internet: https://www.alphabeta.com/wp-content/uploads/2019/02/digitrade_indo_eng_1-pgview.pdf.

International Monetary Fund, 2018, "The Digital Revolution in Asia: Disruptor or New Growth Engine (or Both)," Chapter 5 in Regional Economic Outlook: Asia and Pacific, World Economic and Financial Surveys (Washington).

Kinda, Tidiane, 2012, "Foreign Ownership, Sales to Multinationals and Firm Efficiency: The Case of Brazil, Morocco, Pakistan, South Africa and Vietnam," Applied Economics Letters, Vol. 19, Issue 6, pp. 551-55. 
Levinsohn, J., and A. Petrin, 2003, "Estimating Production Functions Using Inputs to Control for Unobservables," Review of Economic Studies, Vol. 70, Issue 2, pp. 317-42.

Symantec, 2018, 2017 Norton Cyber Security Insights Report. Available via the Internet: https://www.symantec.com/content/dam/symantec/docs/about/2017-ncsir-globalresults-en.pdf.

Universal Postal Union, 2017, "Integrated Index for Postal Development (2IPD) - 2016 Results." Available via the Internet: http://www.upu.int/en/theupu/strategy/2ipd.html.

Woetzel, Jonathan, Jeongmin Seong, Kevin Wei Wang, James Manyika, Michael Chui, and Wendy Wong, 2017, "China's Digital Economy: A Leading Global Force," McKinsey Global Institute Discussion Paper, August.

World Bank, The, 2016, World Development Report: Digital Dividends (Washington).

Yang, Zhuofan, Yong Shi, and Hong Yan, 2017, "Analysis on Pure E-commerce Congestion Effect, Productivity Effect, and Profitability in China," Socio-Economic Planning Sciences, Vol. 57, pp. 35-49. 